\title{
Roberto Mantovani (1854-1933) and his ideas on the expanding Earth, as revealed by his correspondence and manuscripts
}

\author{
Giancarlo Scalera \\ Istituto Nazionale di Geofisica e Vulcanologia, Roma, Italy
}

\begin{abstract}
Roberto Mantovani (Parma, 25 March 1854-Paris, 10 January 1933) - a musician and geologist trained in the Duchy of Parma - was a Consul in the French island of La Réunion at the end of the nineteenth century. In 1878 drawing general conclusions from the similarity in shape between the facing banks of a river that flowed in a volcanic fracture, and the way in which the layers corresponded, Mantovani formulated a mobilistic theory, attributing the moving apart of the continents to the expansion of the entire planet. This theory is more general than that of Wegener from the first decades of the following century. Mantovani's hypothesis was officially recognised by the French Geological Society in 1924, which incorporated it in its body of legitimate ideas. Encouraged by Bourcart in 1924, Wegener quoted the Italian in his famous book as one who offered ideas extraordinarily close to his own. A letter of Mantovani to Wegener, and the sceptical answer of the German scientist, have been recently found. In his letter Mantovani shows a greater awareness of the predecessors of the continental drift than Wegener himself. Mantovani continued to disseminate his idea up to the last years of his life. A final pamphlet, of 1930, was printed with this dedication: «to the mathematicians, physicists, astronomers, geologists, and anyone interested in the great enigmas of the Universe». His biography has been reconstructed thanks to the correspondences carefully conserved in the archives of the Italian Ministry of Foreign Affairs, the Ethnographic Museum Luigi Pigorini, the Società Geografica Italiana, and in the private files of his direct descendants.
\end{abstract}

Key words biographies - Earth sciences history expanding Earth

\section{Introduction to the correspondence}

In May of 1910, Raffaele Cappelli, President of the Società Geografica Italiana, received a letter containing the following words $\left(^{1}\right)$ :

Apart from a few regions that are still little known and the two, strictly polar ones, the Earth's surface is

Mailing address: Dr. Giancarlo Scalera, Istituto Nazionale di Geofisica e Vulcanologia (INGV), Via di Vigna Murata, 605, 00143 Roma, Italy. now perfectly explored so that, in our opinion, no further important geographical discovery is possible. Yet, it is precisely that perfect awareness of the shapes of all the seas, all the continents and islands that has now led us to an important discovery. [...]

The discovery in question is the natural complement to the theories that two illustrious Italians had first supported. Everyone, in fact, knows that with the discovery of the new world, Columbus demonstrated that the Earth was round. Then, along came Galileo, who maintained that the Earth was moving and, by chance, a third Italian came along in the elite company, to prove that the Earth is expanding!

What is most curious to me is the fact that the third one is, in fact, myself. It does not matter, however, whether I or someone else made the discovery. The discovery itself is what is most interesting. By no means: having found out that the Earth expands, obviously very slowly; but continually, is of primary importance for geography, astronomy and paleontology as well. [...] 

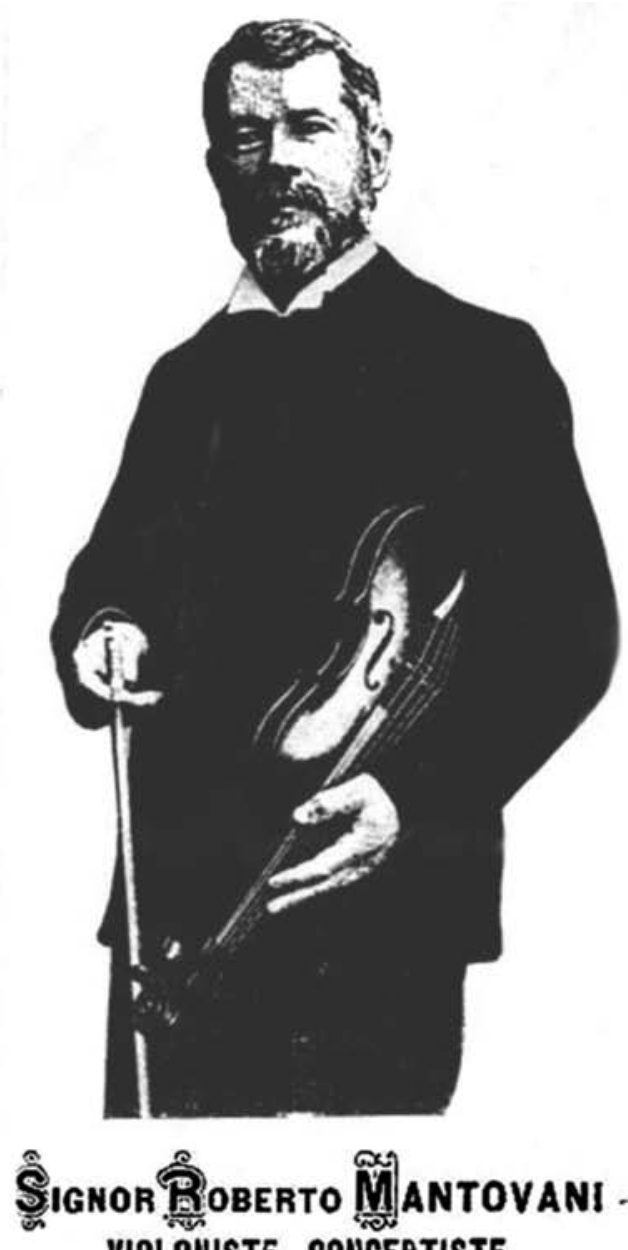
VIOLONISTE CONGERTISTE

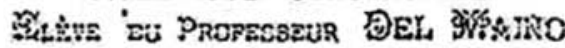
et du Célèbre SIVORI

Premicr prix de violon «à l'âge de 12 ans 》 eu Conservatoire royal de Parme; miédailld et diplomé; $M \mathrm{~cm}$ bre de plusieurs Sociêtés scientifiques, etc.

nonne des lecons de chant et de tous les instruments á corde (all kind of strings instruments).

\section{Adresse :. YILLA SIVORI}

\section{Boaleyard Surcon!}

SAIn B. SERVAN

Fig. 1. Photographic portrait of Roberto Mantovani in a publicity of his Scool of Music in Saint Servan. It is the first page of a three folded brochure.
And the certain, totally visible evidence of the ancient but nevertheless ongoing expansion of the layer that makes up the Earth's surface strictly belongs to the Geography.

It came from the Breton town of Saint Servan, and was written by the violin teacher Roberto Mantovani (fig. 1), formerly honorary Italian Consul on the French island of La Réunion and once member of the Società Geografica Italiana (Italian Geographic Society). An article on planetary expansion was enclosed. It had been published the previous year in the journal Je m'instruis and was accompanied by two clippings from French gazettes containing news items on Mantovani and his conferences about problems of global tectonics, volcanism and earthquakes. With these references, he asked to be allowed to set forth his idea of expansion in a lecture to the Società Geografica Italiana (the answer has not been found).

Mantovani's words show too much enthusiasm and self-assurance for the author not to be considered to be among those exalted individuals who proposed ideas that were not well founded. The expansion of planets was a hypothesis that had never clearly arisen in western culture before the second half of the nineteenth century $\left({ }^{2}\right.$ ) (as had been the case for the idea of Earth's orbital motion, which had already existed in Ancient Greece). Even to welleducated people, it might have seemed rather odd. At that time, Mantovani had not yet come into full contact with academic circles and his way of expressing himself was not tempered by the usual astuteness and tact of institutional researchers.

In 1929, the article in Je m'instruis was quoted by Wegener in the fourth edition of his book Die Entstehung der Kontinente und Ozeane with these words (p. 3 of the 5th edition):

In 1909 Mantovani offered his ideas on continental shift, illustrating them with several maps. His ideas differ from mine in part, and, in part, there are surprising points in common, as for example, those on the ancient grouping of the southern continents around southern Africa.

The German scientist was induced to cite Mantovani from an article by Jacques Bourcart 
from 1924 (Gohau, 1990) which emphasised the points in common between the conceptions of the Italian and those of the German meteorologist (Bourcart, 1924, pp. 563-564):

It is curious to note, in the history of science, that when a new hypothesis is put forth, it generally turns out that it has been simultaneously conceived by various scientists. $[\ldots]$

It is interesting to point out, that Wegener was not the first to have a notion of the idea of continental shift, as imagined by the learned meteorologist from Hamburg, and up till recently unknown in our circles. $[\ldots]$

In December 1889, M.R. Mantovani presented a note to the Société des Sciences et Arts of La Réunion on Les fractures de l'écorce terrestre et la théorie de Laplace, in which he explained the shape of the oceans in terms of a fan-like continental shift. [...]

Here, a discussion of Mr. Mantovani's explanation of this shift, Earth's expansion, cannot be included. It was, however, curious to note that Alfred Wegener had not been the first to foresee the movement of continental masses. Given the rarity of periodicals in which Mr. Mantovani published his notes, he could never have been aware of the ideas of his predecessor.

That same year, the Italian was introduced in Paris as a member to the French Geological Society by the renowned geologists Pierre Termier and Paul Lemoin. He, too, wanted to come into direct contact with Wegener in order better to explain the reasons why the German could not lay claim to priority over the idea of continental shift. In the draft of a letter to Wegener, still among the Mantovani-family documents, he wrote (fig. 2a) $\left(^{3}\right)$ :

\section{Dear Professor,}

I read with great interest your theory on continental shift in the translation of M.M. Reichel published by A. Blanchard - Paris. 1924. [...]

Kindly allow me to bring to your attention the fact that observations on the similarity of the coasts of Brazil and Guinea had been made by Saint-Beuve, a French critic, towards 1860 . Another, similar, but further developed observation had been made by Edward Forbes quoted by Darwin in his work The Origin of Species published in 1859. According to Darwin, this Forbes claimed that all the continents and islands must have been joined together in a relatively recent era. Darwin did not accept this, and, for this reason, did not develop the subject.
For my part, I visited various points in the Indian Ocean in 1878 and, in September of that year, I reached the island of La Réunion (Bourbon). Visiting the river of Saint-Denis, near the city of that name and capital of the island, I noticed that the ramparts below which the river flowed had perfectly coinciding curves and I concluded that this river must have been a fracture caused by volcanic activity on the island from ancient times.

Since I tend to make generalizations about the facts, I wondered if a sea would not likewise have been a great fracture of the Earth's crust. Looking at my atlas, I indeed discovered that all the seas had coasts with corresponding shapes despite the enormous distance sometimes separating them.

In 1884 I presented my observations to the famous astronomer C. Flammarion who found them quite singular and interesting. In December 1889 I presented a note on Les fractures de l'écorce terrestre to the Société de Sciences et Arts of the island of La Réunion which was published in the Bulletin of that Society in 1889.

From my observations I had noted that all the continents and islands must have made up a single block in the far distant past. As a totally natural and incontestable consequence, the Earth, in the first period of its evolution, must have been much smaller than it is now; its diameter must, in fact, have been a third of the present one. The surface film of the Earth's membrane had split due to the force of expansion of the inner gas from the core which gradually and extremely slowly stretched the aforementioned membrane. As a result, continents and islands necessarily shifted.

In this correspondence, it is understood that Mantovani himself did not think he had been the first to conceive of continental shift, but just expansion. He also was not aware of at least three predecessors, the first one, Thomas Dick, an eclectic scientific writer that on p. 93 of his book of 1838 Celestial Scenery made considerations on the similarities among the opposite Atlantic coasts, and on the possibility that those continents was once in contact (Goodacre, 1991). Also Antonio Snider-Pellegrini - who first drew a map of the continents before and after the «supercontinent breakup» (Snider-Pellegrini, 1858, engraving N. 9 and N. 10 between p. 314 and p. 315) and proposes huge decreasing of the Earth's size during the days of biblical Genesis (Snider-Pellegrini, 1858; Scalera, 1999, p. 168) - was apparently unknown by Mantovani. 
a)

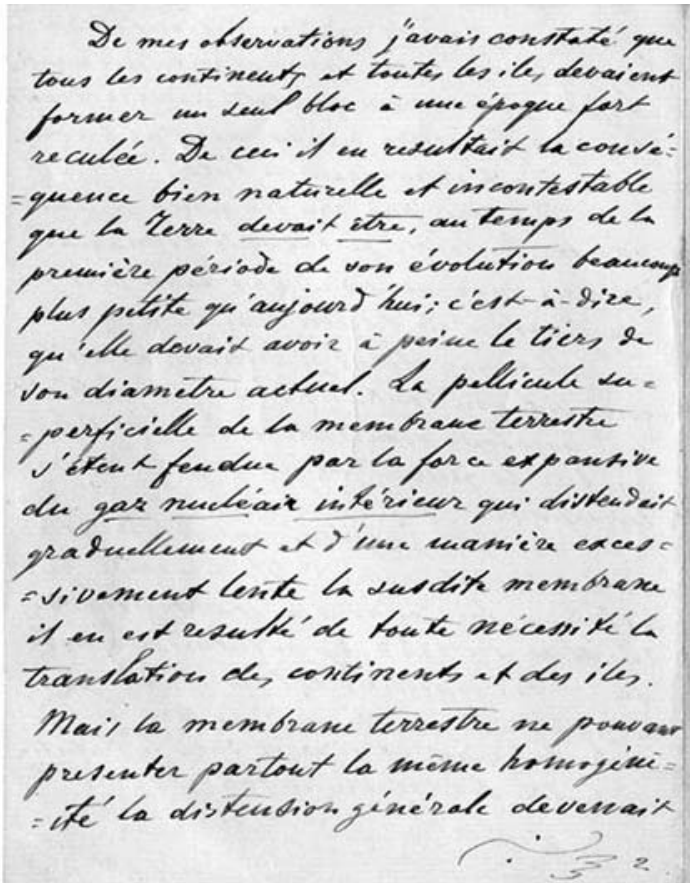

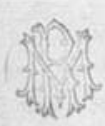

$$
\text { Monsicen le Vofesteur. }
$$

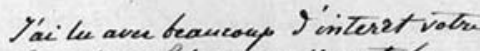
théoric ven by banslations continentaley

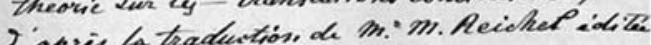
aprestandeard - Paris.1924.par a. Stanche bji trouve cette phrase: cesten 1910 que pour la premiere fois, lidé des-tianslations conkrneutales - me vinta l'esproti en contiderant la carte da glate ss fus vubitement prappie de la remarcable concesdance des cótes da l'atlantryece, mais estimant par trop nivarisemblable lidei da leur ancien embortement, fi me en'y arré

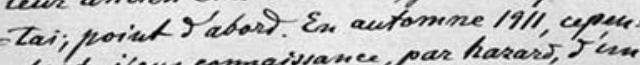
dant, jeur comrarisance, par hasas, Jen campite render verieutifigere ite. b)

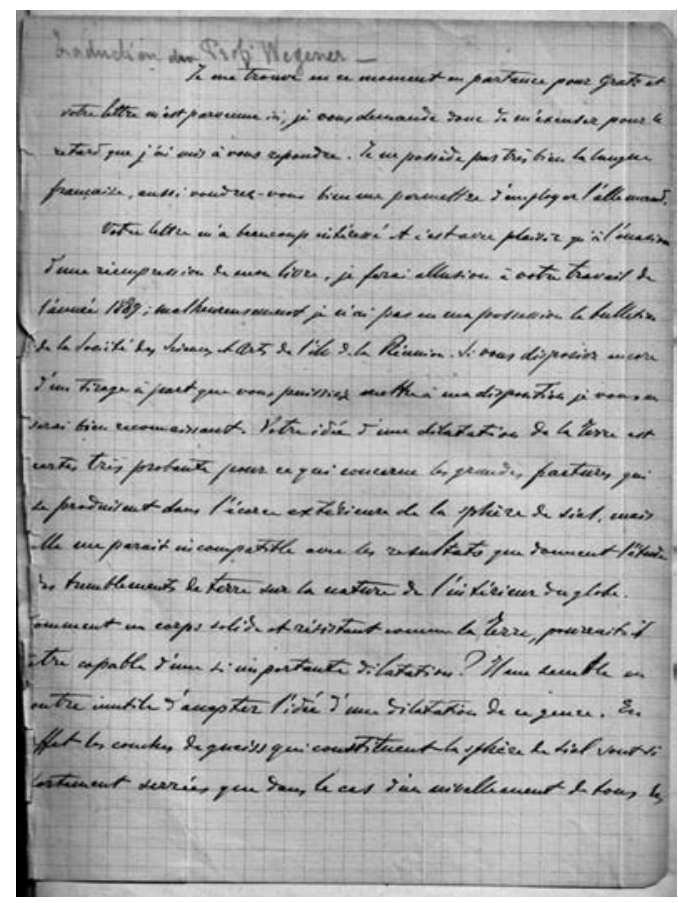

Fig. 2a-c. a) Rough copy of the letter of Mantovani to Wegener (property of Yvane Mantovani Poirier) with the aim to made clear to the German scientist that the priority of the idea of the continental displacements is antecedent to Wegener and Mantovani itself. See the translation in the text. b) The translation in French of the answer of Wegener to Mantovani (property of Yvane Mantovani Poirier), conserved by the Italian among the pages of the book of the German about the continental drift. See the translation in the text. c) The answer of Mantovani to the scepticism of Wegener. The Italian wrote at page 209 (sheet 48) of his manuscript La dilatation planetaire: Such an objection is simply specious because it is completely impossible to assume that the outermost shell of the Earth has been able to contract so much as to cover a surface area less than a quarter of the total surface of our planet. In addition, this is all the more true because the author of the objection admits that «the idea of an expansion of the Earth is certainly very convincing as far the huge fractures that occurred in the outer crust of the sphere» are concerned. 
c)

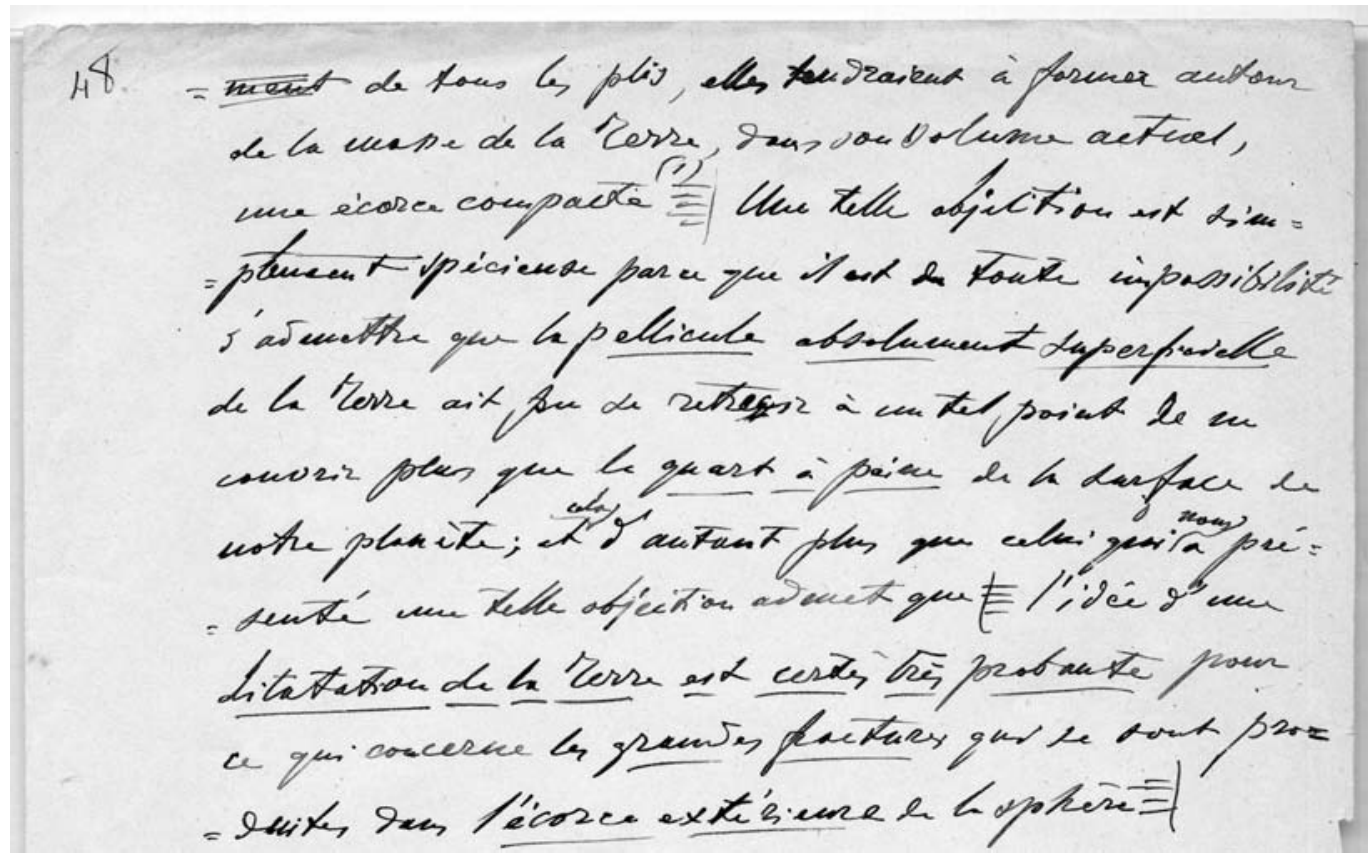

In the field of the expansionists $\left({ }^{4}\right)$, Mantovani did not mention the Scottish geologist and chemist Richard Owen (1810-1890), first President of the Purdue Indiana University and son of the social reformer Robert Owen (17711858; founder of the American egalitarian community New Harmony, Indiana). Richard Owen had his first training in geology at Hofwyl in the Swiss Alps and wrote in 1857 a treatise on the Earth that were interpreted as growing like a biologic organism. Likewise neglected by Mantovani was Captain Alfred Drayson, another eclectic writer which in a page of his book of 1859 The Earth we Inhabit: Its Past, Present and Probable Future published a cross section of the Earth comparing its past (near half radius) and present size (Carey, 1988, pp. 137138; Noël, 1989, p. 30). Finally Mantovani had no knowledge of the book of the Russian engineer Jan Yarkovski, published in French in 1888 , about the nature of the gravity, which deduced - as one of the consequences - the expansion of the Earth.
The original document of Wegener's reply has been lost. It exists only its translation from German to French, which is still attached to the first page of Mantovani's copy of the book $L a$ Genèse des Continents et des Océans published by Blanchard in 1924, translated from the third German edition by Reichel. Wegener replied (fig. 2b):

I am about to depart for Graz and your letter reached me here, so I beg your pardon for the delay in replying to you. I do not have a very good command of French, so kindly allow me to use German.

Your letter was of great interest to me and, when my book is reprinted, I shall be pleased to refer to your work of 1889; unfortunately I am not in possession of the bulletin of the Société des Sciences et Arts of the island of La Réunion. If you still had a copy that you could make available to me I would be very grateful. Your idea of Earth's expansion is certainly very convincing as far as the large fractures in the outer sial sphere are concerned, but it seems to me to be incompatible with the results that studies of earthquakes offer on the nature of the inner Earth. How could a body as solid and rugged as the Earth expand to such a de- 
gree? It seems to me, moreover, of no use to accept the idea of this sort of expansion. In fact, the layers of gneiss of the sial sphere is composed are so tightly packed together that in the case of a levelling of all the folds, they would tend to form a complete crust around the Earth's mass, within its present volume.

Aside from this fundamental problem that you, as I had done, pointed out many of the particularities of the theory of movement it would be very interesting for me, I repeat, to further explore your stimulating work.

Alfred Wegener - Graz 27 June 1924

Wegener expressed his doubts about the possibility of Earth's expansion because he thought the planet was rigid and solid. Indeed, it was only in 1926 that Harold Jeffreys established that a liquid nucleus was necessary. He based his conclusion on global rheological considerations. Prior to that date, geophysicists had thought the planet to be generally solid, since both the $\mathrm{P}$ and $\mathrm{S}$ waves were propagated over a long distance whereas in much of the nineteenth-century geological tradition, it had been thought to be liquid. This disappearance of the $\mathrm{S}$ when passing through the liquid nucleus had not been considered with any degree of certainty. In any case, Wegener could not escape Mantovani's reasoning that all the opposite shores of the oceans could be joined back together to form a continuous fabric, one which would obviously have a size smaller than that of present-day Earth. He then quite cleverly invented a counter-argument, which enabled him to explain the opening-up of all the oceans over a constant Earth's diameter: the contraction (due to subsequent folding) of all the continents. Topologically equivalent to expansion, this line of thought was then defended, independently from Wegener, by the French scientists Chevallier and Cailleux (Cailleux, 1968, p. 212; Cailleux, 1976; Scalera and Meloni, 1991, pp. 209-210; Scalera, 2001, pp. 352-353). Now, however, it encounters insurmountable difficulties.

Mantovani was not discouraged by Wegener's reasoning (fig. 2c) and, with greater energy, developed arguments in favour of expansion. $\mathrm{He}$ had already had experience in producing long manuscripts - which, however, he did not succeed in publishing. Among his papers there is a notebook of about 190 pages entitled La radiation universelle, 1912, and a subsequent, extend- ed version (Mantovani, 1932b) having the same title, whose aim was probably to write something that would have the weight and, hopefully, the impact of Wegener's book on the general public. The second part of this long text (Mantovani, $1932 b$ ) in manuscript form with figures - from $p$. 164 to p. 263 - has come down to us thanks to the loving care of his descendants.

The first part was perhaps that text La terre grandit (Mantovani, 1930) badly printed in Parma by printers who were not at all up to the task, a booklet which is still conserved in some Italian libraries (Palatina of Parma; the Biblioteca Nazionale in Rome; The Library of SGI Società Geografica Italiana).

This latter, long manuscript, which has yet to be studied together with the new material furnished in November 2003 by the heirs, appears, upon a first cursory reading, to be much more mature than the 1910 one, and full of reasoning based on geological as well as geomorphologic considerations drawing on the thencurrent literature. Interaction between the author and the French Geological Society had been fruitful.

Mantovani's attempts to present his ideas to the Italian Geographic Society continued in 1930 with a new letter to the Society's secretary saying $\left({ }^{5}\right)$ :

Dear Sir,

Parma, 20 September, 1930 - VIII

I have been residing in Paris for many years and came to Parma last July to see many of my relatives.

Prior to returning to France I should be very pleased to communicate to, or rather, give a lecture before this highly honoured Geographic Society on continental morphology in the presence of His Excellency, the Head of State, the Honourable Mussolini.

I am taking the liberty of addressing myself to your Honoured Society to find out whether and, if so, when this might be possible.

Confident in the kindness of your Society, I wish to apologise for my forwardness and to express my highest regards to you.

Prof. R. Mantovani

Strada Cairoli 10 - Parma / Paris - Rue Marcadet 151 bis

The postal services of the time were more efficient that the present-day Priority-post and 
the Italian Geographic Society secretary informed Mantovani $\left({ }^{6}\right)$ :

Rome, 22 September 1930 - VIII

Dear Professor,

In reply to your letter of 20 September, I wish to inform you that the possibility of obtaining the opportunity to give a lecture in the presence of the Head of Government is not to be hoped for.

As for that of giving a lecture to the Members of the Italian Geographic Society on the subject you propose, this would certainly be a pleasure. Since, however, there is a Lecture Commission, it would be proper to submit to the judgment of this body the question as to whether or not such a lecture would be appropriate, here or elsewhere.

If you wish to send either a copy or a detailed summary, I shall take it upon myself to inform you on this matter.

In the meantime, in case you deem it appropriate to become a member, I am enclosing a form.

Yours sincerely,

The Secretary

Mantovani answered shortly thereafter from Paris and sent a copy of the short essay La Terre Grandit, printed in Parma with corrections in the margins, which has already been mentioned. There may have been an exchange of letters in between. He explained that the errors were due to the illness and absence of the director of the printing works $\left({ }^{7}\right)$ :

Paris, 8 Nov. 1930

Dear Sir

When I had the honour of presenting you with a copy of my booklet La Terre Grandit I forgot to mention that that work was full of typographical errors. I deeply regret this and beg your forgiveness.

The booklet was not corrected because the director of the printing house was ill for several weeks and the workers could not understand the French-language text despite my many corrections. Finally, I was obliged to withdraw the work, which was not completed.

I had then wished to give a lecture to this Royal Geographic Society on the «continental shapes» since these come entirely within the domain of Geography. For that purpose I would have found the maps and globes necessary for my demonstrations thereby avoiding the possible objection that the maps were adapted to my own purposes.

Since it was not merely a hypothesis but a very important discovery involving in their entirety the physical laws and all the present-day astronomical conceptions, I thought, not on my own behalf which is of little significance, but for the glory of Italian science, that the present of His Excellency the Head of Government at the lecture would be highly appropriate to give the proper emphasis to an extremely important Italian discovery. Indeed, if Christopher Columbus discovered a new world, planetary expansion is leading us directly to the discovery of a new Universe.

In the meantime, I am taking the liberty of enclosing another example of my booklet in which I have indicated in red the typographical errors and all the important sentences.

Once again, I beg your pardon and wish to express my profound respect.

Prof. R. Mantovani

Paris, 151bis Rue Marcadet, 18th arrondissment

Now, Mantovani seems to express himself in more measured and modest tones than he had done in the letter of 1910, but he continues staunchly to defend the objective truth of terrestrial expansion. Once again, as had been the case previously, he awaited a reply from the Italian Geographical Society, but we do not know what this was. Perhaps the time was not yet ripe, especially in consideration of the fact that the idea of planetary expansion is not still readily accepted today in Academic circles.

\section{Biographical Notes}

Although Roberto Mantovani was well known to few specialists (Egyed, 1963, quoting a 1962 private communication of Fairbridge; Carey, 1976, p. 23; Carey, 1988, pp. 90, 92, 138; Muir Wood, 1985, pp. 56-58; Gohau, 1990, 1991; Segala, 1990, p. 115 in foot-note; Scalera 1995, 1997a, 1999 p. 166; Scalera 2003) for his ideas on the evolution of the planet Earth, little had been known of his life and work up to then. Contemporary French historiography had judged him to be an enigmatic character (Gohau, 1990, 1991), and dealt with him briefly. This research offers a biography of Mantovani which is still incomplete, and based on documents found in various historical archives in Rome and Parma, and only from November 2003 on additional documents provided by the descendants.

Roberto Mantovani was born in Parma on 
25 March 1854, the second of two brothers, of Luigia Ferrari (Golese, 10 April,1827-?) and Timoteo Mantovani who died six months after Roberto's birth. Luigia Ferrari, now in dire straits, entrusted the elder child, Oreste (Parma 6 May 1852-?), to an uncle and aunt from Baganzola. She had a permanent job working in the house of Don Pietro Bellati (Parma, 1818-?) and kept Roberto with her. Don Pietro was a priest and teacher at local charitable institutions (Parma Demographic Service Archives), and perhaps a distant relative. Bellati offered parental protection to the child and became aware of his precocious intelligence. Although he would have liked him to become a seminarian, he allowed Roberto to enter as a boarder in the Regia Scuola di Musica. Here the young man won the first prize for violinists at the age of twelve and was awarded the Honorary Diploma in Music in August of 1872.

He seems to have completed his education on his own and felt he had a special talent for the exact sciences as well as foreign languages and cultures (from an autobiographical letter, Historical and Diplomatic Archives of the Farnesina, see fig. 3). In 1874, he was fit for military service (Parma Demographic Service Archives). Since he loved to travel, he joined a group of musicians belonging to a theatre group, which went from Algiers to the Island of Mauritius, then to the French island of La Réunion in October. The trip was perhaps made for performances given in honour of the initiation of works for the longest railway tunnel in the world, under Mont St Denis $(10,280 \mathrm{~m})$. It was the third to be built after those of St Gottard and Fréjus), and was carried out by a Piedmontese Italian company (Gohau, 1990; Scherer, 1994, p. 81). At the end of a period of great prosperity on the island, local leaders were attempting to solve the serious problem of communications in unfavourable high-altitude conditions. The numerous public works and viaducts constituted quite a bold venture for that era.

As soon as he reached Saint Denis, Mantovani observed the resemblance between the complementary shapes of the two edges of the volcanic fracture through which the Saint Denis river flowed. Thus, his first idea came to him: he could make a generalization concerning the oceans on the basis of what he had seen on a smaller scale. Young and broke, however, he had no possibility as yet of publishing his ideas. For the same reason, with some regret, he gave up his plans for following several Italian expeditions to Africa's interior, and decided to give music lessons. As a teacher of the violin, he came into contact with the most distinguished Creole families in the area, and married Anna Piet in 1880. She was the daughter of a well-todo pharmacist. Before 1886, she bore him four children Margherita, Luigia, Italo and Roberto (Historical and Diplomatic Archives of the Farnesina). Three other children were born later.

During those years he most certainly devoted himself to developing and refining some of his scientific ideas on which he subsequently published two articles. In 1882 he became a member of the Italian Geographic Society, where he was introduced by the Parliament Deputy and Attorney Enrico Arisi. In 1884 the paleo-ethnographer Luigi Pigorini (Fontanellato di Parma, 1842-1925) wrote to him. He had had Mantovani's name from Mr. Socrate Bellati, perhaps as a friend of the family he had met on holiday and a relative of Don Pietro Bellati. In the letter, he requested that objects from the native culture of Madagascar (fig. 4) be sent to enhance the collections of the nascent Pigorini Ethnographic Museum of Rome (Pigorini Ethnographic Museum Historical Archives). In his correspondence with Pigorini Mantovani proposed a national lottery to finance polar explorations as well as a dictionary of Malagasy to be published through the Geographic Society. The fate of these proposals is unknown. In March of 1886, he requested that the Ministry of Foreign Affairs appoint him to the position of Consul of La Réunion, for which he had the support of Pigorini and Baratieri. In April of 1887 he sent the Ethnographic Museum of Rome two cases containing Creole objects and some from Madagascar (fig. 4). In March 1887, he received the consular licence from Paris and, in May, the exequatur $\left({ }^{8}\right)$ from the Republic of France.

It would be unthinkable for a sharp mind not to come into contact with the intellectual elite of the island, which gathered on the premises of the young Société des Sciences et Arts (founded in 1856; Scherer, 1994, p. 66). Here he put forth 


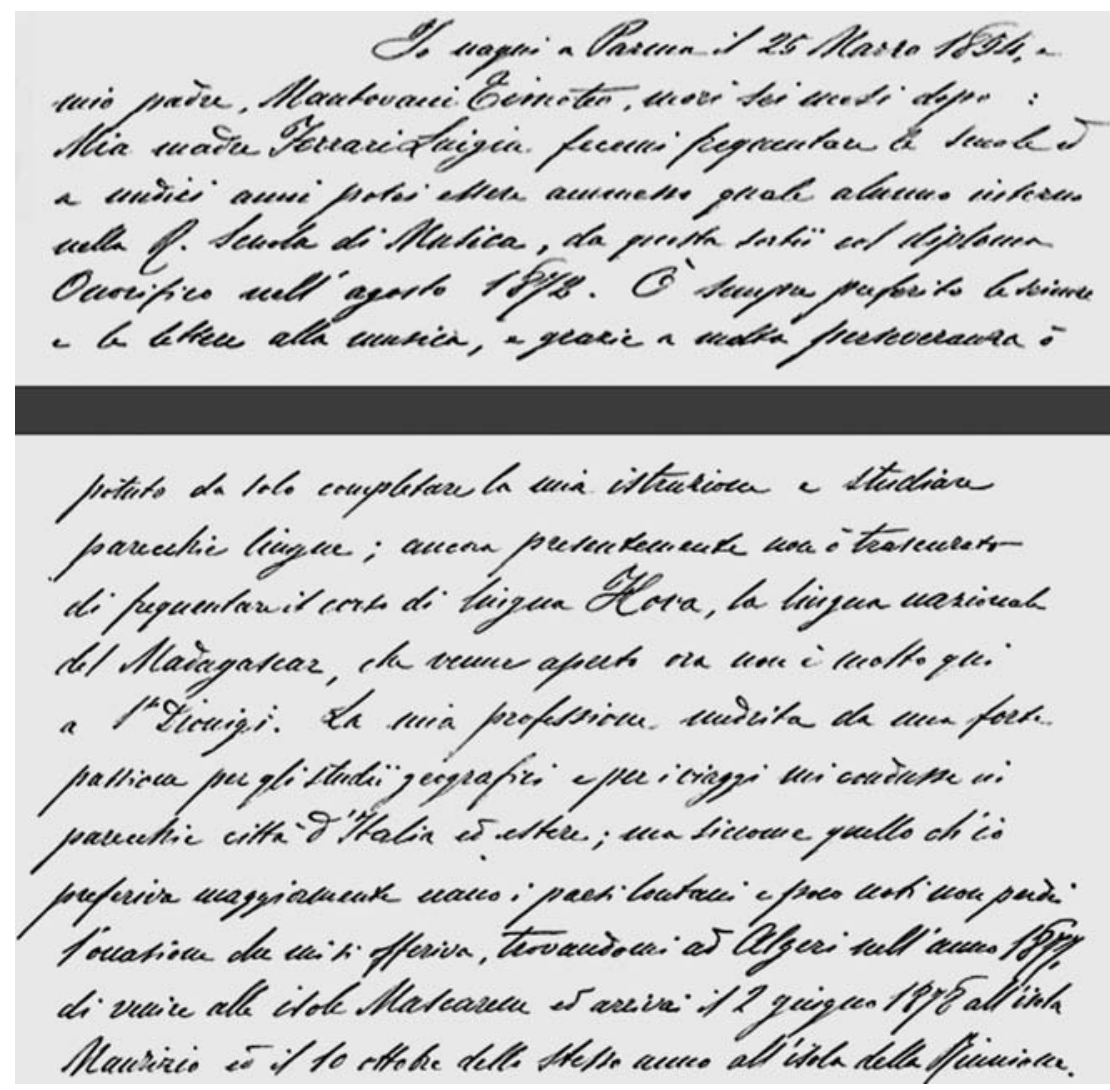

Fig. 3. The autobiographical letter of Mantovani which was sent to the Ministry of Foreign Affairs in the occasion of his request for the appointment as Consul of Italy at La Réunion Island (Archives of the Ministry of Foreign Affairs, Rome). This letter of Mantovani says: «I was born in Parma on March 25, 1854. My father, Timoteo, died six months later. My mother, Luigia Ferrari, directed me to the studies, and at the age of $11 \mathrm{I}$ was accepted as boarder in the Royal School of Music, where I was conferred with the Honorific Degree, in August 1872. Having always preferred the exact sciences and literature to music, it was with great perseverance that I succeeded in completing myself my studies and learning several languages $[\ldots]$ ».

his idea on reforming the calendar (Mantovani, 1888), which had been submitted to an international contest on the subject. Although his proposal for 100-day-long months and 1000-day years was not practicable, his concern to obtain a universal time system, freed from the periodic motion of Earth's orbit and democratically usable for all the heavenly bodies was clear. Hence, his thought was directed towards general principles, and details linked to contingent matters were of secondary importance to him.
For this, he received the praises of Camille Flammarion. A year later, he published his old idea of Earth's expansion. This idea had been worked out over a long period and always related to general processes operating in the universe. When Flemmarion was made aware of the idea of the expanding Earth, in 1884, he encouraged Mantovani to defend and develop it.

La Réunion had now plunged into years of disastrous economic decline. The ruling classes were fleeing to other shores, nearby or back in 


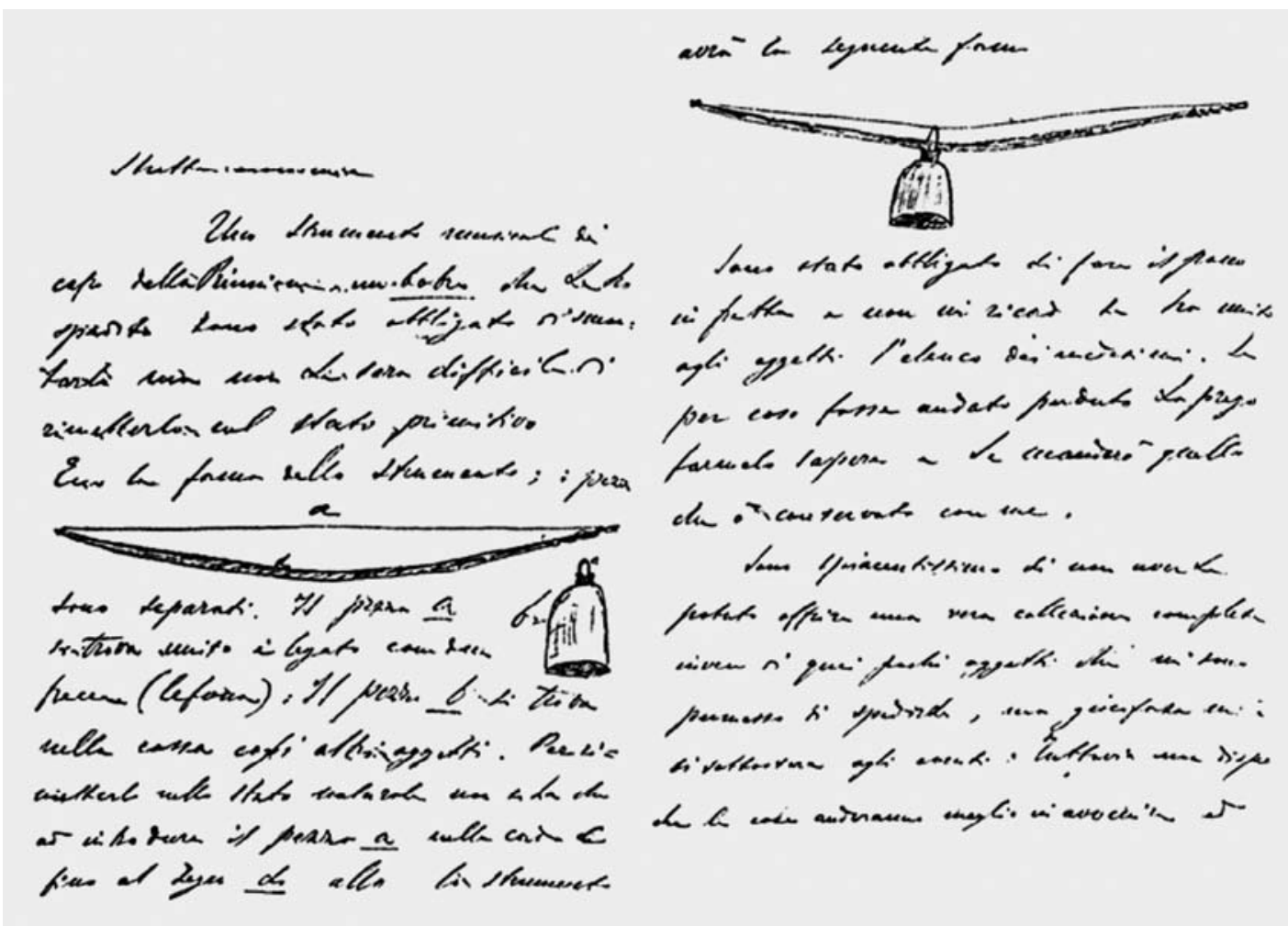

Fig. 4. Fragments of the letter of Mantovani to the Italian ethnologist Luigi Pigorini, in which the delivering of some musical instruments of Madagascar is announced, with a drawing of them (Archives of the Pigorini Ethnographic Museum, Rome).

Europe (Scherer, 1994, p. 82). Mantovani likewise took part in this exodus and began to leave the island and his job repeatedly, probably in order to find means of support during those extremely difficult years. We find him in July of 1893 at Port Luis (Mauritius) giving music lessons then, in 1895 at Quatres Bornes (Mauritius). In 1896, he was sought out at the Ministry by a fellow Italian from Venice. Mantovani made numerous trips to France and London where he lived for three years with his family and finally decided to put an end to the hardships encountered on the island. He took a leave of absence from his job and went to Northern France, to Saint Servan - a tiny Breton village, now a part of St Malo. In 1899, he was summoned to the Ministry, which asked him to re- sume his position as Consul. He replied that he planned to return in future, but, family matters obliged him to delay his departure: his wife needed to be in a cooler climate, and, according to him, the plague was raging in La Réunion. Medical records confirm that a plague was raging along the costs of the Indian Ocean during those years and claimed victims in Europe as well (Galizzi and Palmer, 1985). The executives in the Ministry were annoyed by his prolonged absences and inappropriate proposals for projects that seemed too fanciful to them a result of a lack of «mental serenity» on his part (a battleship, a Rome-Tunis railway, and the occupation of territories with gold and coal mines). They advised him to resign so that they could appoint a new Consul, which they quite obviously felt 
to be urgent. His resignation took place on 11 July 1900 (Historical and Diplomatic Archives of the Farnesina).

Mantovani settled at Saint Servan in Villa Sivori with his wife and daughters (fig. 5a,b). The villa owed its name to Camillo Sivori (Genova 1815-Genova 1894), a virtuoso of the violin and his teacher, who was the only pupil of Paganini, presenting himself as the continuer of his sublime art. The address was $B d$ Surcouf, now divided into rue Eugène Brouard in the north and $B d$ Henry-Dunant in the south, perhaps the only Italian-style villa (fig 5b) that can be seen in that location today (Petout, 1995; Poirier, 2005). To earn a living, he once again gave music lessons and became greatly involved in performing concerts for charities (Historical and Diplomatic Archives of the Farnesina). Printed materials from that time show that his name was associated with the concert of August 1900 for the inauguration of the monument to Admiral Bouvet. He then gave a concert on 16 July 1902 in the city hall, accompanying the singer Rosse. Finally, he took part in the concert of the Harmonie Municipale of Saint Servan in 1903. There are also records of concerts given by his pupils (Mussat, 1996). Most probably, he came into contact with the very active Société de Musique de Saint Malo (Tuloup, 1984) and research is being performed on this question (Mussat, 1996). In 1902 his mother and his brother Oreste moved to Sorbolo, a village near Parma (Parma Demographic Service Archives).

In France he continued to pursue the idea of planetary expansion, to which he wanted to devote himself, according to a letter. He succeeded in publishing a brief summary called L'Antarctide which contained some maps (fig. 6a,b) in the popular scientific journal Je m'instruis (Mantovani, 1909). Three maps - the «Pangea», its break-up radiating from Antarctica and the $\mathrm{Pa}-$ cific - were often reproduced in historical essays and papers on the subject (e.g. Bourcart, 1924, p. 564; Dubard, on Le Figaro 23 March 1958; Muir Wood, 1985, p. 58; Scalera, 2000, p. 347; Scalera 2003a, pp. 71, 73). The mutual position of Madagascar and Australia - which on the map were in contact along their rectilinear margins (eastern and western respectively)
- was defended by Mantovani also in his last pamphlet of 1930 (p. 17). It may be that this Madagascar-Australia contact could have inspired the drawing of a subsequent original «Pangea map» published in 1964 by Olive and Baronnet (1964, p. 36), in which eastern Madagascar is separated from western Australia only by the narrow island of Sumatra. Still today, the position of Madagascar is subject of outstanding debates. Some clues coming from paleontology and biogeography actually can be in favour of a proximity of Madagascar to Indochina, indicating that also this Mantovani's line of thinking shows potential future fruits.

The article on Je m'instruis suggests that there must have been contact with the Antarctic explorer Jean-Baptiste Charcot (1867-1936). Those are the years when Wegener offered his first reflections on continental shift (Wegener, 1912 a,b). At the end of April, 1910, Mantovani wrote a letter to the President of the Italian Geographic Society asking for support from the IGS for a lecture he would deliver in Rome on Earth's expansion (Historical Archives of the Italian Geographic Society). This letter demonstrated his total awareness of the responsibilities he had taken upon himself in claiming a truth which would have far-reaching consequences for all the other sciences. Italian Geographic Society records have yielded no evidence of a response if, indeed, there was one.

It may be that from 1910 to 1924 Mantovani looked after those family interests that, according to him, had called him back to La Réunion. Only a two part paper from 1910 about «prehistoric cosmogony» (with links to the Earth considered as a living organism) and a method for violin technique from $1922 \mathrm{Le}$ secret de $\mathrm{Pa}$ ganini: méthode des méthodes de violon were published by him. This method perhaps really has described some elements of the true Paganini's technique, considering that Mantovani was friend and student of Camillo Sivori, which was the sole student of Paganini and the sole to reach a close imitation of the fingering style of the old master (apart some admitted minor difficulties for the shorter length of his fingers). In this period we have no news of Mantovani's personal life, or of what he was doing during the war, but the post-war period up to 1924 saw 

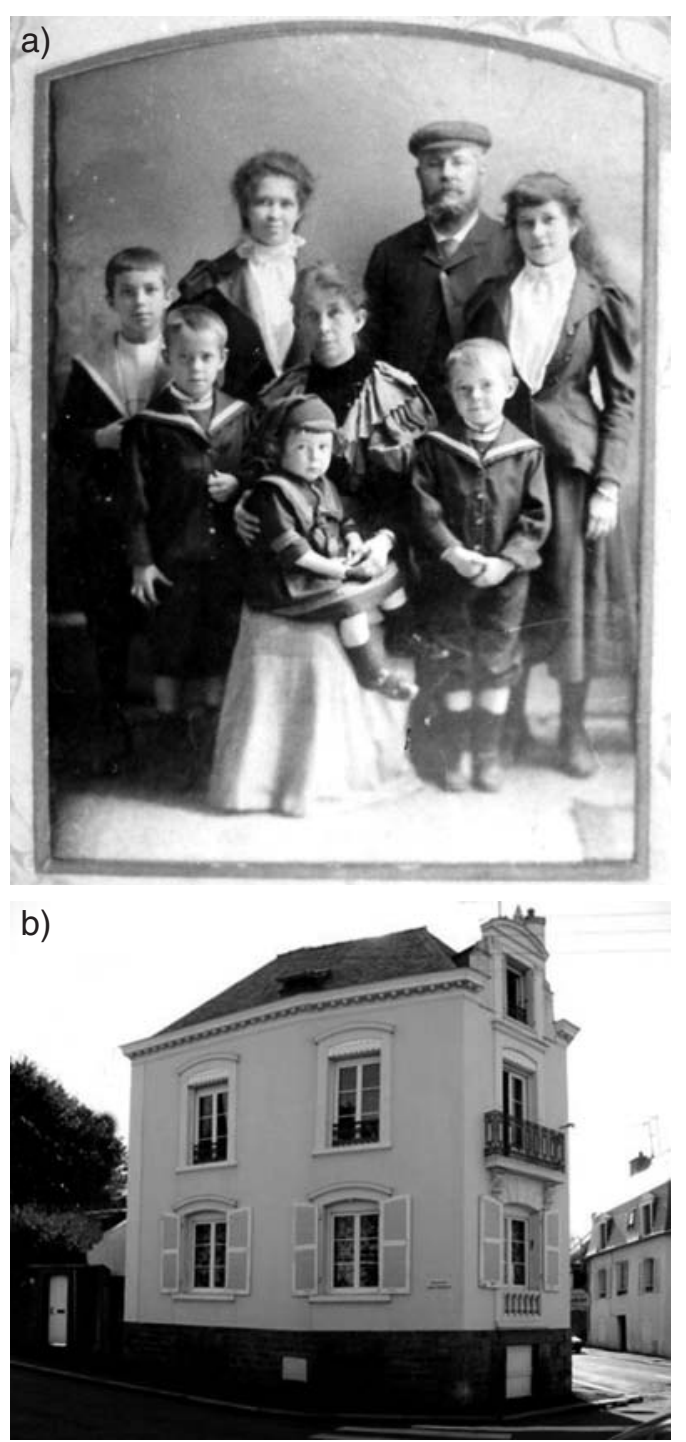

Fig. 5a,b. a) The Mantovani family. From left to right: Roberto (same name of the father, was engineer of the Paris Metro), Carlo (was professor in the Gymnasiums), Margherita, the little Itala (dead at 15 old), Anna Piet, Roberto Mantovani, Renato (was Governor in Indochina and father of Yvane), Luigina. b) The Italian-style Villa Sivori in Saint Servan France, Bd Surcouf, where the Mantovani's family settled. The Boulevard is now divided into rue Eugène Brouard in the north and Bd Henry-Dunant in the south. Roberto Mantovani dedicated his house to Camillo Sivori (Genova 1815 - Genova 1894), a virtuoso of the violin pupil of Paganini and teacher of Mantovani. considerable heavy buying and selling of land at La Réunion.

A sugar price rise during the war had enriched the big farmers of the island who reinvested their capital (Scherer, 1994, pp. 86, 87). In any case, Mantovani moved to Paris where, as we discovered, he became the owner (called «landlord») of an entire building in 1924 (near 151 bis, Rue Marcadet: built In 1910 by the architect Emile Blaise, it is still standing). In the year of his arrival, he was introduced as a member of the Société Géologique de France by the academicians Termier and Lemoin. An article by Bourcart (1924) brought him international renown and obliged Wegener to quote him (Gohau, 1990).

Mantovani began to correspond directly with Wegener and continued to produce long manuscripts that he failed to have published by French publishers (Mantovani, 1910, 1932a, 1932b). Later, in 1930, Mantovani published his last (but this, too, must be verified) work, in French, printed by the author at the Ferrari printers in Parma (whether or not this is a Ferrari, a relative on his mother's side, is yet to be ascertained. He may have had this published in Italy to save money). The work contains a dedication to Count Gaetano Manzoni, the Italian ambassador and plenipotentiary in Paris, who, on 1928, was among the signers of the International Treatise for the Renunciation of the War (Treatise of Paris «Briand-Kellog») and later became a Senator (Vistoli, 2007). The second part of this work in print (withdrawn in incomplete form due to too many errors resulting from the lack of experience of the Italian printers with the French language) is perhaps the unpublished manuscript of 103 pages with numerous maps sketched freehand which seems to have been written for the purpose of compiling a book with solid argumentation and documentation comparable to Wegener's.

Death came to him in Paris in 1933, on 10 January. He had almost reached his eightieth year. A few months before, on 7 June 1932, Louis Houllevigue - a university professor of Marseille and science writer - wrote on the newspaper Temps the commentary Causerie scientifique - La revision des longitudes. In this 
a)

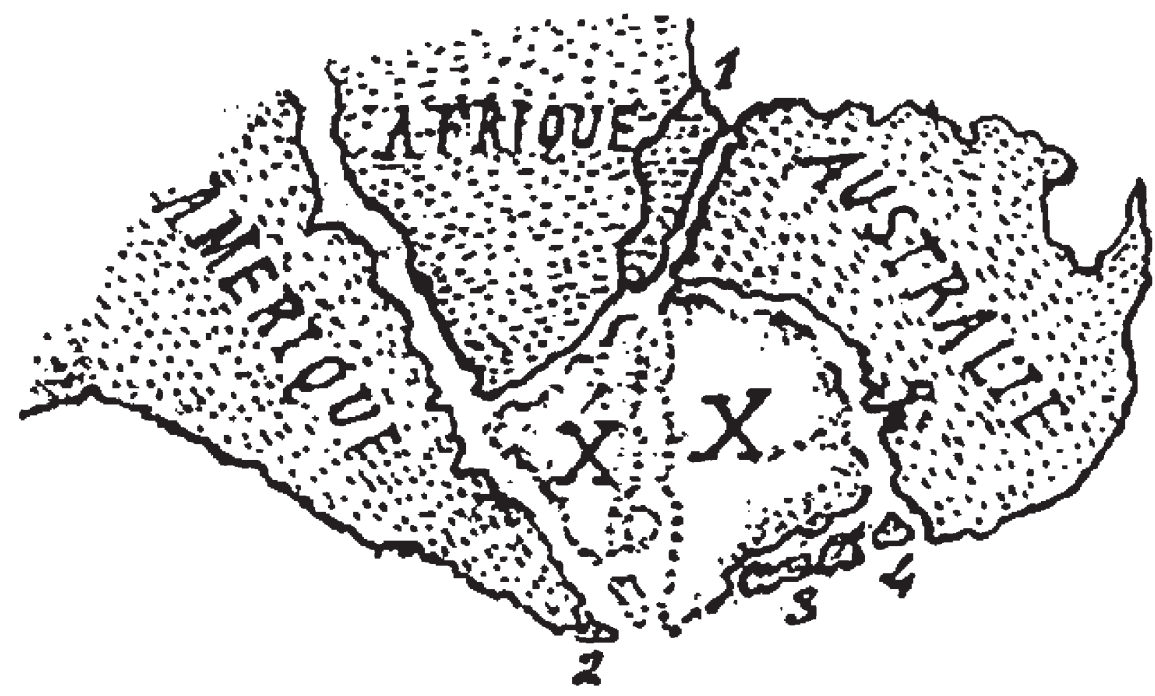

b)

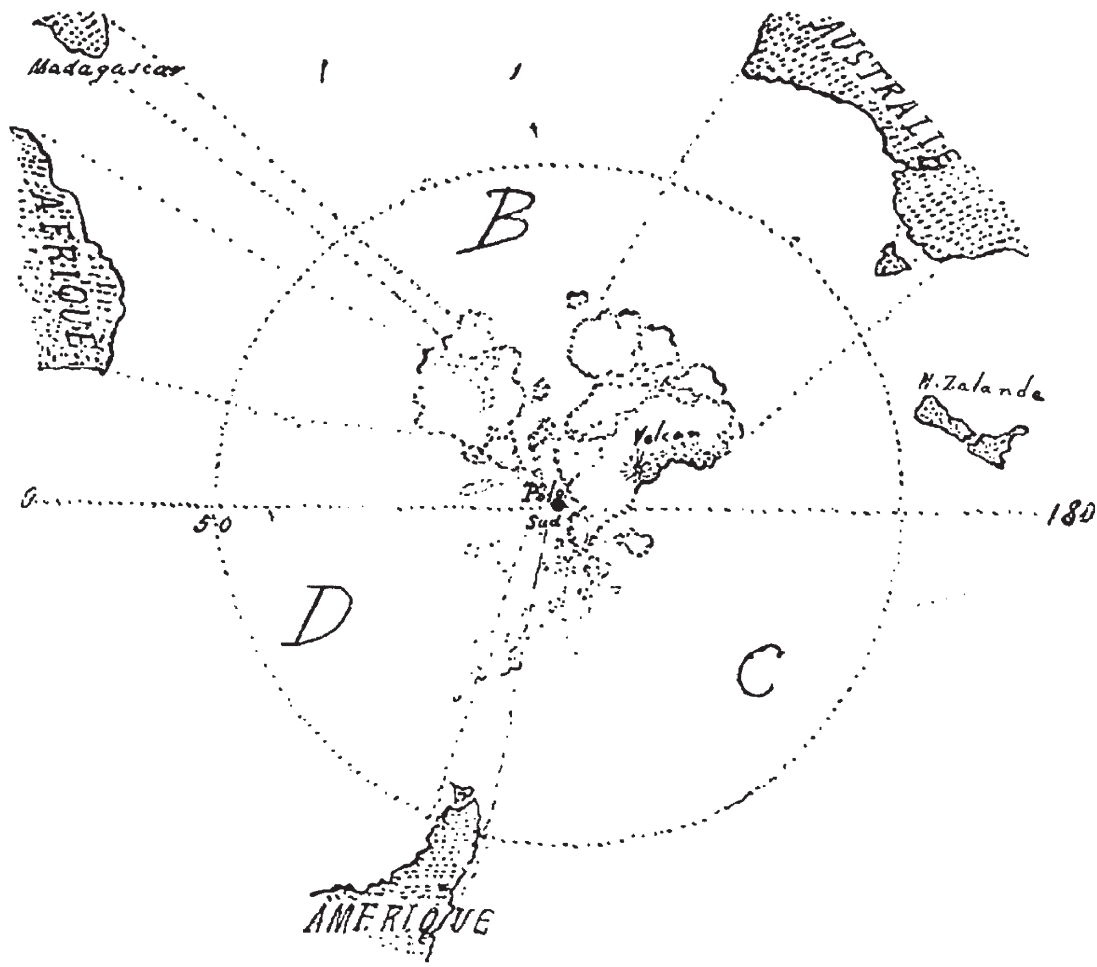

Fig. 6a,b. a) The continents reconstructed as a «supercontinent» by Mantovani in the work published on the magazine Je m'instruis in 1909. It is very similar to the Pangea depicted by Wegener starting from 1912. b) In the same paper on Je m'instruis the breakout of the continents away from Antarctica was depicted, which continent was hypothesized by Mantovani as constituted by several islands. The hope of the Italian was that the Antartic expedition of the explorer Jean-Baptiste Charcot (1867-1936) - to which the maps were given - could find evidences in favour of the real existence of an archipelago. 
text the possibility to check and confirm the Wegener's drift theory was recognized in the new geodetic-astronomic method of measuring the longitudes variation. Mantovani was still once cited as a French proponent of the same theory with a priority of several tens of years, because it was recalled that he begun to think about the matter in 1878 (Houllevigue, 1932):

This continental wandering is continuing also today, and Wegener has tried to confirm it scrutinizing different measures of longitude performed on different time. For example these measurements seems to show that the North American continent is moving away progressively from Europe, while the Greenland was approaching at a rate of a dozen of meters for year.

After all, this theory is old as the human restlessness. Does had Plutarch verbatim wrote «The Earth is a disc floating on the sea, of which the River Ocean fills the edges»? Without going back so much, I can point out that a compatriot of ours, Mr Mantovani, has upheld, since 1878, an equal doctrine, and also more logically explained. But the geophysicist of Hamburg has had the gift to give to his theory a fascinating form, which has fixed on it an universal attention.

After this last encouragement, Mantovani was recalled two years after his departure in an article of Roger Simonet (1899-?) a French prolific science writer on the newspaper Temps:

Wegener has had a precursor more original of him but of extremely little renown before that $L e$ Matin - it will be soon passed ten years - exposed his conceptions. Not only Mantovani, before the German geographer, observed the conformity of the Atlantic coasts of America and Africa, but also that the same possible correspondence - clue of a suture dating back to thousand of years ago - exists between the Pacific coasts of America and Asia. Then, he said, we can admit the hypothesis, for the origin of the sea and the continents, of an Earth littler than the actual size, which has been fragmented by the action of the pressure of the gaseous inner material $[\ldots \ldots]$.

\section{Mantovani’s Ideas}

In his 1889 work (pp. 41, 42, 48), Mantovani wrote $\left({ }^{9}\right)$ :

It was towards the beginning of 1879 and I had just arrived in La Réunion. I was walking along one of the edges of the River of Saint-Denis, and noticed a perfect resemblance in the shapes of the two banks of this river; not only do the parts of one of the edges that jut out correspond to the hollows in the other, but also the various layers of lava followed the same order on both sides. So I thought that the bed of the river of Saint-Denis could only be a fracture in the ground due to volcanic activity on the island. Since I am in the habit of drawing general conclusions from my ideas, I also asked this question: if a river is a small fracture in the ground, why wouldn't a sea be a large fracture in Earth's crust?

I returned home, looked at a planisphere, and was quite astonished to observe that the coasts on opposite sides of the sea generally had the same similarity in shape as I had noticed between the two opposite edges of the river of Saint-Denis. That greatly encouraged me to study this new way of envisaging the folds, bumps and hollows of Earth's crust. [...]

If, in our imagination or on a sphere, we bring together all the edges of the seas, we reduce the surface of our globe to a quarter of the original; and, if we add to our calculations the coming together of edges, fractures that have produced rivers, lakes, valleys, plains, etc., we easily arrive at a globe that closely reminds us of the small planet Mercury, because of its dimensions. We are thus obliged to recognise that Earth's crust has considerably increased in surface at the expense of its liquid and atmospheric envelopes.

It seems to hear a voice from the past, from the end of the 18th century, which already had proposed, albeit without the more radical generalization of Mantovani, the same ideas about observed conformities. Indeed, in his Telluris theoria sacra (1680-1689), Thomas Burnet wrote (Italian translation in Morello, 1979, p. 108):

In no manner I challenge that the Earth globe breaks up to its centre, in its deepest bowels, and also below the abyss or region of the waters. It was fractured also the outermost region of the globe - the one we inhabit - where the mountains are, the rivers flow and the ocean laps against. And the same occurred to the innermost region, up to the depth where the caves are hidden, from which the underground waters spring, where fossils can be found and from which the metals can be extracted. The senses and the reason witness the dispersion of its parts. From the external aspect of some cliffs it is clearly recognizable that these massifs undergone fractures, and, in some straits, the opposite cliffs corresponds so precisely each other that this fact has lead many people to suppose that once they were joined. [...]

The chasm of the sea, with its steep and shattered reefs, with the huge boulders that make uneven the 
coasts or that emerge from the sea bottom, do indeed demonstrate a lacerated body? What is the advantage to recall the islands separated from the continents and the lands disrupted and torn in thousands of ways, on the external and in the interior, because in a place there are parts of the land excessively uplifted, and in an another one depressed, and elsewhere broken and evidently moved away mutually each from the other? This state of confusion and perturbation must not have occurred without a catastrophe and such catastrophe without fractures.

The comparison of the Burnett and Mantovani ideas shows once again the evolution of the thought about the Earth dynamics passing from 17th to 19th century (see also the François Placet passages of 1668 translated in this paper) and the full participation of Mantovani through the influence of his readings and frequentation of the intellectual community of his time - to the Earth sciences progress and his further evolution with respect to the cultural main stream, in which the ideas about displacements of large masses, boulders, islands was accepted as legitimate ones.

Mantovani was to keep up with developments in Geology and Paleonthology, and he was emotionally involved in this subject. $\mathrm{He}$ paid particular attention to news from expeditions in distant lands, which could confirm his theories. From the work L'Antarctide in $\mathrm{Je}$ m'instruis (1909) we know that he shared his maps showing the evolution of Pangea and his hypothesis that the polar continent had split into two or more fragments to the doctor, Antarctic naturalist and explorer, Jean-Baptiste Charcot (1867-1936; the son of the neurologist of the Salpêtrière of Paris Jean Martin Charcot and teacher of Sigmund Freud). He hoped that Charcot would return from his second voyage with new and favourable discoveries, as well as geological and paleonthological evidence. Charcot left the harbour of Le Havre on $15 \mathrm{Au}$ gust 1908 on the ship Pourquoi-Pas? The ship had been fitted through government financing after the exciting success of the first voyage of 1905. The Italian said (Mantovani, 1909, p. 597) $\left({ }^{10}\right)$ :

When he returns, we will see if it is necessary to make considerable corrections in the details, since, as far as the whole is concerned, the origin, shape and extent of Antarctica will remain exactly as we have just determined.

He was already highly familiar with the correspondences that geologists had found for the southern continents (Mantovani, 1909, p. 597) $\left({ }^{11}\right)$ :

[G]eologists have found great similarities between the lands which presently make up South America, southern Africa, Madagascar and Australia which is easy to imagine, since, as we have just seen, all of these lands now so far apart from one another were originally joined together.

But he wanted to find something more, arriving at a general theory to explain the tapering of the continents towards the south, imperfect for Africa and absent in Australia's case (Mantovani, 1909, p. 597) $\left({ }^{12}\right)$ :

Consequently, it is obvious that since Antarctica had been formed by the fragments of these continents that had remained behind as they were pushed aside, it necessarily had to form a great archipelago possessing considerable geological affinities with South America, Africa and Australia.

On the map (Mantovani, 1909, p. 596), he represented Antarctica as an agglomerate of small fragments. But two of these, marked with X's, were wider and tapered, located in such a way as to complete Africa and Australia. His statement was almost prophetic since nowadays we divide Antarctica into two areas with very different features, different geological histories, and shifts taking place reciprocally along the mid-Antarctic mountain belt dividing it. This was not all, when one considers that fact that the lands of Antarctica are largely below sealevel due to the isostatic influence of the weight of the ice cap. However, the presence of two fragments of the tapered extensions of Africa and Australia does not seem to have been confirmed. This conviction of Mantovani's might have come from the famous aphorism XXVII of the second book of the Novum Organum (1620) of Francis Bacon (1561-1628).

The aphorism says:

[I]n the configuration of the world in its great geographical stretches the examples of conformity are 
not to be neglected. Africa and the Peru region, with its land mass that descends to the Straits of Magellan have similar isthmuses and similar promontories, and this cannot be by chance. Similarly, the Old and New Worlds correspond to one another in so far as both expand northwards, whereas in the south they are narrow, tapering towards a point.

During his second and last exploration of the Antarctic regions, Charcot named numerous islands, capes and mountains. He identified Adelaide Island, passed by the Faure Islands and sailed along the huge Alessandra Island. This all suggests that when the naturalist returned to France, Mantovani, who had been awaiting fresh data, may have considered that at least his hypothesis had been confirmed: that of an Antarctic continent consisting of an archipelago. Apparently science, for Mantovani, involved complex navigation through palaeogeography, geography, cartography, explorations, geology, paleontology, and the search for observed data to confirm his theories was an integral part of his methodology.

But the great novelty in the 1909 paper was the mapping (fig. 7) of the Pacific view (Mantovani, 1909, p. 595): dotted lines were drawn between pairs of geographical points which once were in contact while today they are separated by the huge extension of the Pacific basin. The idea was that the corresponding points were in contact before the dilatation of the Earth. The enlarging of huge fractures formed all the oceans. We have to wait the sixties to find the same kind of lines for the Indian and Atlantic oceans in plate tectonics. According to plate tectonics this is not true for the $\mathrm{Pa}$ cific Ocean, because in this case the plates movement is inverse and tends to closing. The 1909 Pacific map was forgotten, and only the Mantovani's Pangaea representation (fig. 6a) is reproduced today in some books dealing with the history of science (Muir Wood, 1985)

The problem arises as to what influences there could have been on Mantovani's thought, since he was apparently isolated from the academic world and did not have access to specialised data. But was he indeed isolated? At the time, it was fairly common to find scientistpriests who held degrees, such as astronomer and geologists of the caliber of Secchi, Hagen
(Scalera, 1999), Cecchi, Mercalli, and Stoppani. One of Bellati's brothers may have been a doctor with a degree in Natural Philosophy (Bulzoni 1997).

If research in this direction yields answers, the idea that the French book by Sinder Pellegrini (1858) may have been in Bellati's library will gain credence. The book is primarily religious, hence totally unknown among scientists and having no influence on them. It may, otherwise, have been in some religious institute that he went to regularly. In any case, the book had its impact and was reviewed in numerous papers, among which was the Courrier FrancoItalien (Various authors, 1859); hence it is reasonable to suppose that comments appeared in the Italian press, given Sinder's Italian origins. The strong cultural ties between the French and Parma are not to be forgotten, either. Parma was a former grand duchy placed under the control of Marie Louise, the wife of Napoleon Bonaparte. A Society for Conversation and Reading, with a conspicuous library, was - and still it is - active in Parma from 1858 (but with different denominations and more ancient origin in 1722). Perhaps it is because of these readings from his youth that Mantovani spoke with such self-assurance and without providing examples of certain paleonthogical connections between the coasts on either side of the oceans in his first work (Mantovani, 1889) about fractures in the Earth's crust.

The fact that Mantovani was presented to the Société Géologique de France in 1924, and published that same year the article Les points de contact entre la théorie de la dilatation planétaire et la théorie de la dérive des continents de Wegener (Points in Common between the Theory of Planetary Expansion and that of Continental Drift of Wegener) (Mantovani, 1924), must be seen in an historical perspective. To be sure, his ideas on Earth's internal structure seem naive nowadays, but the beginning of that century marked the first time that the structure of the Earth had been «under observation» due to the newly created observational seismology (Oldham, 1906; Brush, 1980). The seismometers of Emil Wiechert (1861-1928) from the beginning of the century had been designed for this observation, and they were equipped 


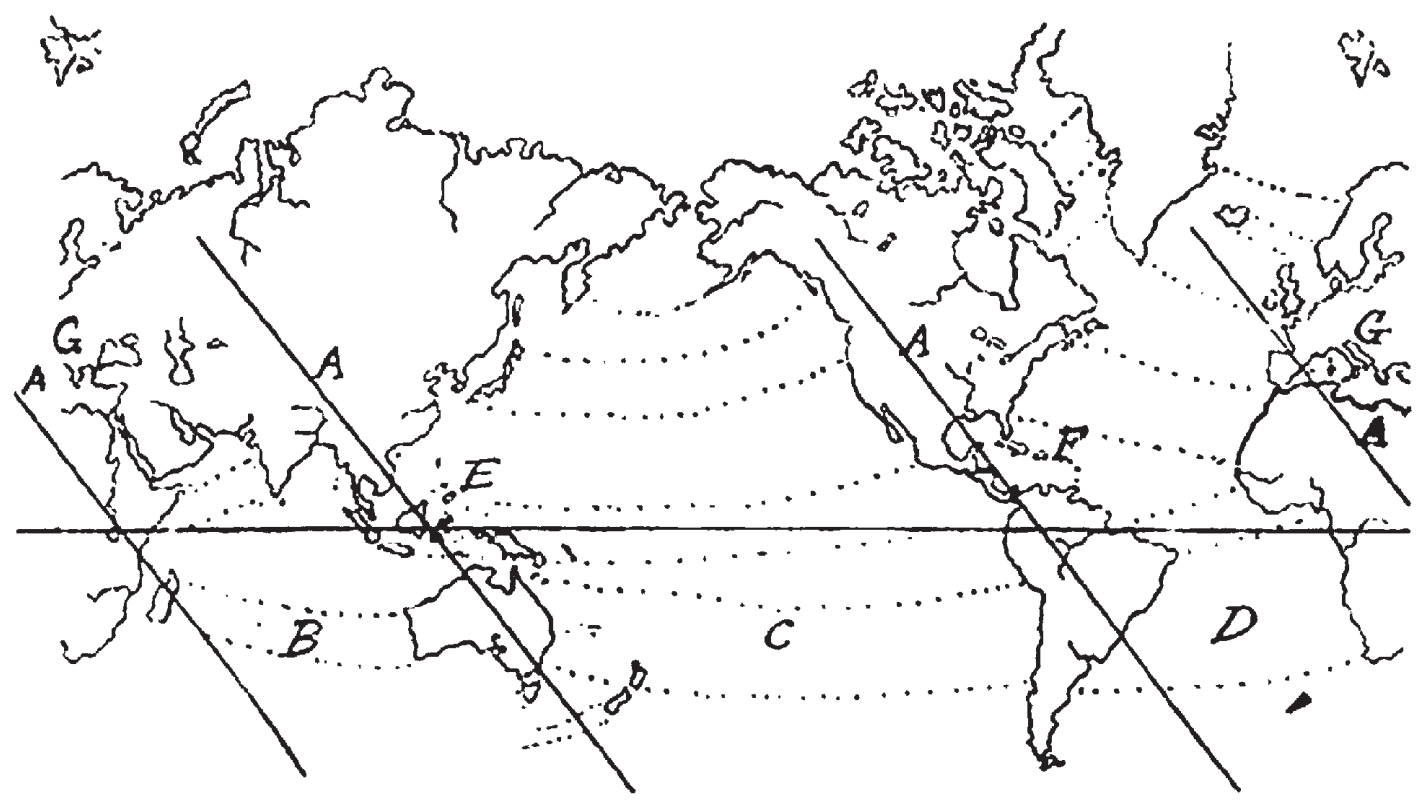

Fig. 7. The global map drawn by Mantovani to describe the Earth's expansion concept in the work published on the magazine Je m'instruis in 1909. Dotted lines are traced between pairs of points located on opposite oceanic coasts, to indicate that they were once, in the geologic past, coincident, and that the interposed ocean was closed. The dotted lines was traced also across the Pacific and then all the oceans was closed and as final consequence the Earth must has had, in the past, a smaller size than the present one.

with dampers (which merely permitted to distinguish the different phases of the seismic waves: $\mathrm{P}$ waves, $\mathrm{S}$ waves, $\mathrm{Pn}, \mathrm{Sn}$, etc. allowing to disclose Earth's layered structure) but debate on the actual necessity for this instrumental improvement raged for a long time (Proviero, 1926). The progressive revealing of the internal structure by the geophysicists Richard Dixon Oldam (1858-1936; outer core, 1906), Andrjia Mohorovicic (1857-1936; crust, 1909), Inge Lehman (1888-1993; inner core, 1936), must have been seen by non-specialists, geologists and many other scientists of the period as uncertain discoveries, subject to considerable revision if not refutations. Geology was not closely linked with geophysics as it is today and geologists held ideas about the constitution of the planet which, in actual fact, were pure hypotheses not supported by observation (the article by Brush offers a good idea of the complexity of opinions as to the Earth's interior as well as the sudden changes in views) and surely marked by the conceptions from the past such as «the great abyss» from the work of $1680 \mathrm{Tel}$ luris theoria sacra by Thomas Burnet (a liquid interior of the planet related to religious conceptions, one which gave origin to the waters of the Great Flood), and by his successors (Morello, 1979, Chap. III) or predecessors. To explain volcanism, many geologists preferred a molten interior just a few kilometres in depth. Pierre Termier (1922, p. 323) offered the following ideas on the Earth's structure:

It was first said: the Earth is made up of a thin, solid crust surrounding a liquid core and held up by this core. The heat from the core passes through the crust and dissipates into space. The core contracts and becomes too small for the crust which folds and wrinkles from then on in order to maintain contact with its liquid support. Nowadays, given when we know, from the observation of earthquakes, the elasticity of Earth's crust, we must speak in somewhat 
different terms. Earth's interior is a heavy gas, as strong as steel, and the liquid or melted region, called a pyrosphere, can only be an area that is not very thick, between the solid crust or lithosphere and the gaseous barysphere.

These ideas are quite similar to those of Mantovani who, at the beginning, preferred a gassy interior, for which no further details were supplied. Perhaps thanks to his interactions with the Parisian academic world, the Italian scientist refined his ideas about the structure of an Earth with a gassy interior. Certain points recall the elaborate Cartesian theories (Morello, 1979, Chap. II, pp. 69-83). According to Descartes (1644) a subcrustal liquid layer could coexist, in some phases of the Earth's evolution, with a central core made of thin solar material, and the collapse of the crust into this inner liquid shell led to the tectonic evolution of seas and mountains. This Cartesian phase of collapse also recalls the final phase of inward collapse of the crust which, according to Mantovani, brings the expansion of planetary bodies to a conclusion with their transformation into comet-like bodies. In 1930, the Italian showed his interest in the bold innovations of relativistic and quantum physics (Mantovani, 1930). Indeed, he was not a physicist and tended to misinterpret several basic facts; for example, Mantovani was convinced that about halfway along the Earth's radius, the force of gravity of the upper layers predominated over that of the lower ones, hence, the core matter was thrust outwards contributing to planetary expansion; he was unaware of the fact that the gravitational influence of a spherical layer is zero at any internal point thereof: the gravity at a point in the interior of a planet is due, with a reasonable degree of accuracy, only to the ideal sphere of underlying matter. But he nonetheless arrived at an explanation of the Earth's composition which provides a bridge between the old and the new (Mantovani, 1930, p. 15) $\left({ }^{13}\right)$ :

Everyone knows that on our Sun's surface jets of matter are produced that have such force as to be capable of reaching a height equal to over a quarter of the Sun's diameter. What is the Earth with its diameter of 12,000 kilometres in comparison with such eruptions?

The tops of certain streams of this matter reach an area 800,000 kilometres high where the direct action of the Sun's attraction is reduced. This part of the solar matter which has been thrust out follows in part the Sun's rotation due to the whirling motion it has received and turns back on itself. In the course of time it forms a tiny planetary cell following the example of the mother cell, the Sun. We then have all the elements making up the solar family and whose individual members represent the complete series of phases in the evolution of each of them. Every evolution of a planet can thus be summarised in terms of three distinct periods: $1 .-$ the Whirling Period 2. the Planetary Period, and 3. - the Comet Period. The Earth is presently in the planetary, or, in other words, developing phase.

This «cellular system of the universe» (Mantovani, 1930, pp. 15-19) was basically a Cartesian conception, but still has important exponents today. To cite just one famous example, the studies of the astronomer Halton Arp (1989) led to a cellular vision for galaxies as well, which emit jets of matter at the ends of which quasars are to be found, interpreted as new daughter proto-galaxies at the beginning stage of their evolution. Modern constructions in the physics of solar neutrinos suggest the wish to verify these conceptions, even if this desire is not openly expressed. With an ample network of monitoring stations, it would be possible to obtain a neutrino tomography of the Earth offering improved distinction among the materials making up the core. A seismic tomography distinguishes only the wave-propagation velocity without giving any information about materials, which can only be hypothesised on the basis of the cosmology currently in fashion. The lack of solar neutrinos might be ascribable to causes from within the planet rather than external ones.

\subsection{Continental drift}

Mantovani's thoughts and those of the Academician Pierre Termier differ greatly in other fields. Both deal with Atlantis, a subject very much in vogue during the 19th century and shortly after the 1st World war (Ciardi, 2002). The existence of Atlantis was for long time discussed by the more renowned geologists and naturalists like Buffon, Forbes, Darwin, etc. that proposed or considered realistic the possi- 
bility of land-bridges (Von Ihering, 1907). These practicable «bridges» between paired of continents were needed by the fixists to explain transoceanic paleontologic correspondences (Ciardi, 2002). Their existence started to be put in doubt when became evident that their integrated extension covered nearly completely the area now occupied by the Oceans (e.g. see the global map in Handlirsch, 1913, p. 116).

Both Mantovani and Termier were quoted by Sykes in the classic book on Atlantis by Donnelly (1882, revised by Sykes in 1949, p. 42). Termier defended the idea of land bridges. For him, the Platonic Atlantis was a vast continent that had emerged, between Europe-Africa and the Americas, later to be submerged due to a great volcanic event which surely took place on the surface, as shown by the vitreous nature of the lavas (Termier, 1922; lecture to the Paris Oceanographic Institute in 1912; also translated into English in the Smithsonian Reports in 1915). Mantovani once again put forth the basic idea of planetary expansion, causing the fragments of crust floating on the sima to move apart, conserving shape conformities between coasts once in contact. The continental shapes were thus kept and, as a result, there was no possibility of their being linked together by land bridges, which Atlantis might have consisted.

If the better known Termier based all his erroneous reasoning about the sinking of Atlantis on the vitreous nature of the basalts on the sea bottom, a feature he attributed to the cooling of the flows coming into contact with air (Termier 1922, pp. 131-132), but which we now know can occur due to rapid cooling in water, Mantovani, in his work of 1927, overestimated the rate of separation of the continents, and asserted that Atlantis was nothing but the Brazil. 10,000 years earlier, that country was only a few dozen kilometres from Africa. During those years Vening-Meinesz (1926), became involved in the problem of carrying on his gravimetrical campaigns (Vlaar, 1989) and denied that vast continental areas or land-bridges sank.

Just three years later, Mantovani corrected himself in his work of 1930 . He converted to expansion rates that were now much too slow, and abandoned convictions that had cost We- gener his life in Greenland as he attempted to measure rates of continental shift of metres per year. He had been deceived by the inaccurate geodetic measurements of that era (Hallam, 1987; see the rate of a dozen of meter for year that were believed as a realistic value in Houllevigue, 1932, translated in this paper).

Unlike Wegener, the Italian based his estimate of the rate of continental shift and ages of the oceans on the size of the latter, a procedure which would not be considered valid nowadays, considering the fact that all oceans show rocks whose maximum ages are comparable to one another. His initial calculation of the age of the Atlantic was, however, in agreement with the geodetic measurements then available, and with which Wegener agreed. According to the young Mantovani $\left(1889\right.$, p. 43) $\left({ }^{14}\right)$, the oceans began to open up much closer in time to our era (Pleistocene, $\sim 1 \mathrm{Ma}$ ) than what was actually the case (Jurassic, 180Ma),

The age of a fracture must be in direct proportion to its maximum spread, since the most logical supposition is to assume that a single cause, acting uniformly, must have produced all the fractures of Earth's crust.

Hence, the first fracture is the one that formed the Pacific Ocean.

It followed that the Pacific was very ancient and the Atlantic considerably younger, approximately 10 million years (Mantovani, 1927). Hence, the connections between the opposite shores of the Atlantic dated back as recently as prehistoric times. The Italian scientist also provided a detailed description of the opening up of the Mediterranean, in which, based on bathymetry, Sicily was part of the African continent. In the absence of precise dating of the seafloors, it was thus possible for Mantovani to draw extreme conclusions where the correlation between the fragments was not only paleontological but also ethnologic. This is not surprising, either: the Italian scientist's thought was immersed in that flow of geodynamic conjectures about continental shifts, which started with Placet (1668) and his catastrophic shifts linked to the Great Flood. Placet (1668) cites, among the other events pertaining to movements of lands and floods, the original position 
of the city of Messina, which, in prehistoric times was allegedly joined to all of Sicily and Calabria. It then moved away due to great, tumultuous events, a fact reported by Pythagoras. Placet $(1668$, pp. 54, 57, 64, 69) says:

And to begin with Pythagoras, he assures us that Antissa, Pharos, \& Tyre in Phoenicia were once islands, but now joined to the mainland; that the Leucades, however, which were not at all separated, are today girdled by waters and streams; that the city of Messina along with all of Sicily, which was once attached to Italy, subsequently detached to give way to the Sea between them; [...]

$[\ldots]$

Seneca, Tertulien, Lycinus, Marcellinus, Petrus Hyspal, \& several others, assure us that Spain once was part of the African continent; that the Mediterranean Sea was only a Lake, and had no communication with the Ocean, \& that the Straits of Gibraltar were closed off by a clump of earth which connected the two Pillars of Hercules.

$[\ldots]$

All these examples make us aware that the floods and the earthquakes have the force to upset the mountains, to convert fields and valleys into rivers; to buid up hills, to swallow up kingdoms and empires, and to make islands from a number of Provinces once united to the continent.

But if the regional deluges have had so much force to dismember the Sicily from Italy, the Spain from Africa, and to submerge a most great part of the Earth as the Atlantis Island, It is sure that the Flood has made higher ravages, when the cataracts of the heavens have been opened, the abysses have broken, and the Earth has undergone an universal catastrophe.

$[\ldots]$

If we ask to ourselves how is possible that a so huge part of the world [Americas] was formed, I reply that this could have occurred whether by the joining together of many floating islands that mutually fastened each other, $[\ldots]$ or by the destruction of the island of Atlantis, which sunk and caused the discovery of a new land: because the Providence parcels out the empire of the elements in such a way that if something is earned in a part, the same amount is lost in an other. So, a new province has been discovered in the South, while contemporaneously a part of the Holland has been lost submerged by the seawaters.

Later came Buffon, who, on paleontological bases, dated the separation between America and Europe - by subsidence of the interposed Atlantic area (or Atlantis) - to 10,000 years ear- lier. All this created a tradition of belief in a relatively recent opening of the Atlantic that persisted up to the time of Wegener and was also supported by geodetic measurements (spreading rate in the magnitude order of metres per year) strongly affected by systematic errors. These tradiction was often based on a mobilist interpretation of the Atlantis myth, and was opposed to the then prevailing views of the Plutonists. For example, the plutonist Leopoldo Pilla (1805-1848), born in Venafro and professor in Pisa, on p. 301 of his famous Trattato di Geologia (Treatise of Geology) of 1847 had harsh words for the «exaggerated ideas about the effects of earthquakes» opening straits, separating continents, and the support that such ideas had received from Plato's Atlantis story. The abhorred theories in favour of Atlantis were even mentioned in his eulogy (he was killed in 1848 during the Battle of Curtatone) delivered in Sondrio in 1874, perhaps with a bit of malice aforethought. The eulogy was delivered by Domenico Lovisato (1842-1916), who had earned the reputation of being Wegener's precursor due to the mention in a single manuscript (never published) of some mobilistic ideas (very rapid mobilism) linked to the Atlantis myth (Fossa-Mancini, 1924; Imeroni, 1927, pp. 30-32).

As in the case of the Sun's age, the discovery of nuclear energy, the development of physics and related dating methods were what made it possible to extend limits that had long been too narrow, setting the new confines of the geological ages much further back in time (the Sun's age went from 200 thousand years to several billion. The time for the opening of the Atlantic was set back several hundred thousands of years to 180 million). Although his extreme deductions were not confirmed, this did not mean that Mantovani's method was improper: that of putting together correlations coming from various disciplines. In any case, the naturalist, in his work of 1930, perhaps taking advantage of the discussions at the Société Géologique Française, steered a new course, preferring a far slower expansion of the planet and abandoning ethnological correlations (Mantovani, 1930) $\left({ }^{15}\right)$ : 
If provisionally it is admitted a rate of spreading of $1 \mathrm{~mm} /$ century between the coasts of Peru and the coasts of Mozambique (ocean Indo-Pacific), we arrive to approximately to 26 billions of centuries for the Indo-Pacific opening, and to 7 billions of centuries for the Atlantic ocean one.

\subsection{Volcanoes and earthquakes}

As was to be expected from what has already been said, Mantovani's reflections extended to volcanic and seismic phenomena. From the few lines of documentation coming from French national gazettes and regional Breton ones (Historical Archives of the Italian Geographic Society) we know that this scientist considered the volcanic phenomenon a global one activated on a global level, or one which could involve areas very distant from one another at the same time. He also expressed his opposition to the theses according to which volcanoes were activated by the attraction of Sun and planets or electric currents generated by solar activity. It would also seem that he believed that this occasional release of energy from the Earth's interior also involved seismic phenomena for which attempts at forecasting are made.

The dearth of information is such that little more can be said, but it appears obvious that these ideas were at the heart of explanations for planetary expansion. The volcano-seismic phenomena - supported without awareness of expansion also by the Italian, Giuseppe Mercalli (Alfano, 1915), and Darwin $(1840,1897)$ among others - must have been the local manifestation of the gas pressure that made up the planet's interior, whose action slowly gave way to discontinuous planetary expansion. This conception according to which seismic phenomena and volcanoes are linked in overall fashion was common to many researchers at the time. Now this idea has almost entirely disappeared with the widespread acceptation of the theory of plates and the varying rates of convergence and divergence between them. Only recently, some new compelling evidences have rekindled the interest about these earthquake-volcano correlations (Scalera, 1997; 2007; 2008), revealing another precursory aspect of the Mantovani's conceptions.

\subsection{Other concepts}

In addition to the already-mentioned articles published in La Réunion and then in France, two other papers (one paper split on two consecutive issue of Je m'instruis: 22 and 29 May 1910) have been found among the descendants' collection of documents. In this 1910 article the origin of mankind and the Earth's evolution is discussed in connection with ancient Indian cosmologies. The terrestrial Brahman egg depicted in Indian mythologies is judged to be an idea close to conceptions of his time, ones with which the author was in agreement. Mantovani quotes the ideas of S. Meunier and De Launay who considered the Earth to be a living being, and proposed to go beyond these by considering the Earth a living and growing cell - a conceptions analogous to the one of the American Richard Owen, which were expressed in the 1857 book about the Earth considered as a growing seed - and by applying the same concept to the entire Universe, which must, like an egg, be considered stratified (Mantovani, 1910, p. 343) $\left({ }^{16}\right)$ :

The intersidereal medium is likewise full, as is an egg, if you will allow me this expression; and there are currents, swirls and layers of differing thickness just is in our own atmosphere.

As has already been said, Mantovani cultivated highly general metaphysical conceptions to which he attributed great importance, equal, at least, to his conceptions about planetary expansion and very closely related to these. One of his recurring ideas concerned a metaphysical concept of the Universe attributing its evolution to an Universal Radiation (Mantovani, 1912; 1932a). This, related to gravity, caused the expansion of heavenly bodies. There are two, long manuscripts on this subject (of about 190 and 100 pages, respectively). One is dated 1912 and one, reworked up to 1932 whose last sheet is dated 21 September 1932. The preface to the latter was written on 1 January 1933, nine days before his death. It is perhaps that last of Mantovani's writings $\left({ }^{17}\right)$ :

Paris 1 January 1933

Preface

The ideas presented in this book $[$ La radiation universelle, author's note] go back a half century and 
a)

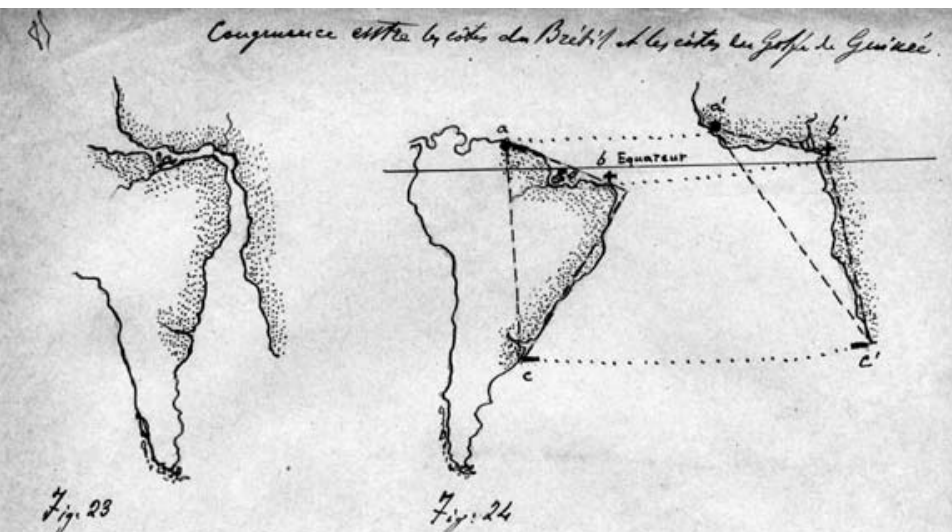

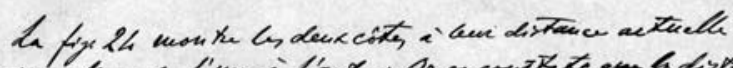

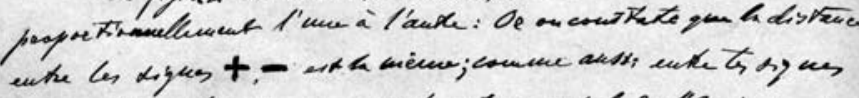

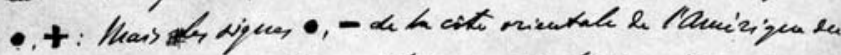

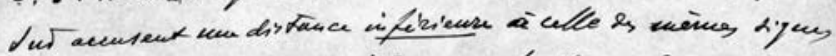

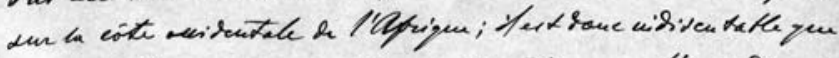

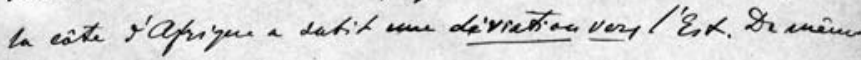

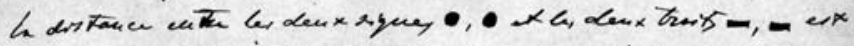

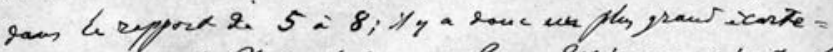

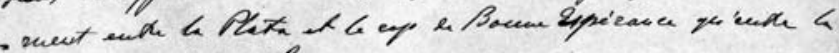
surace Atiersa Lions.

b)

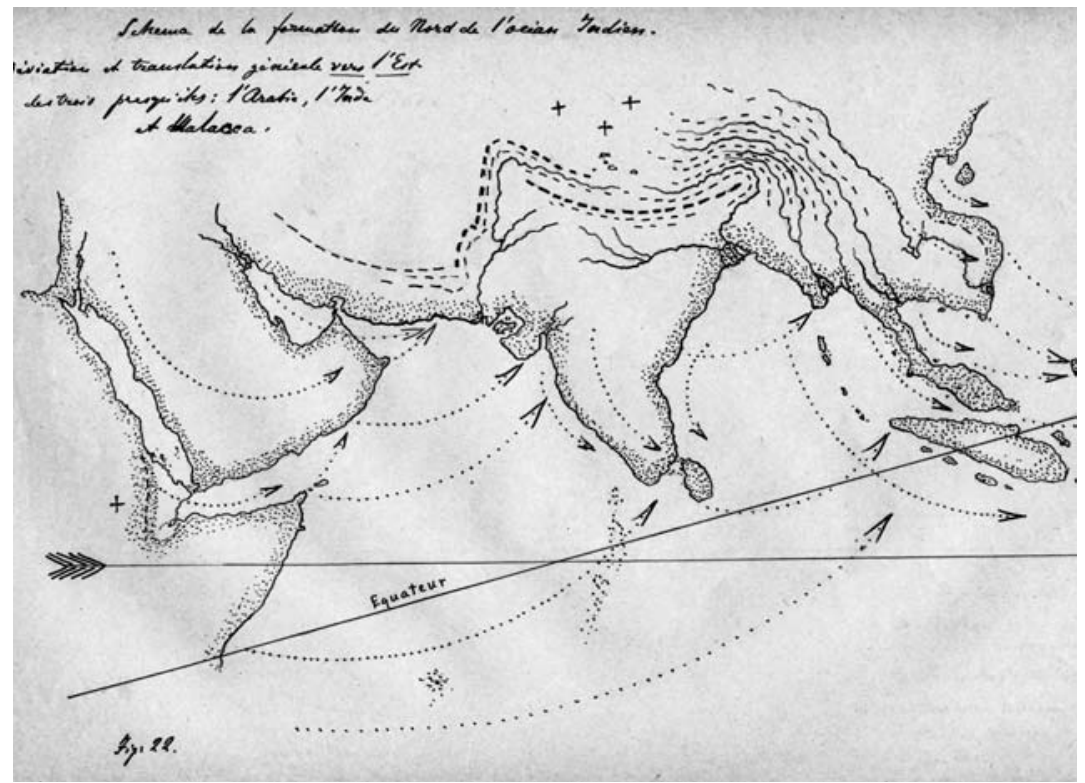




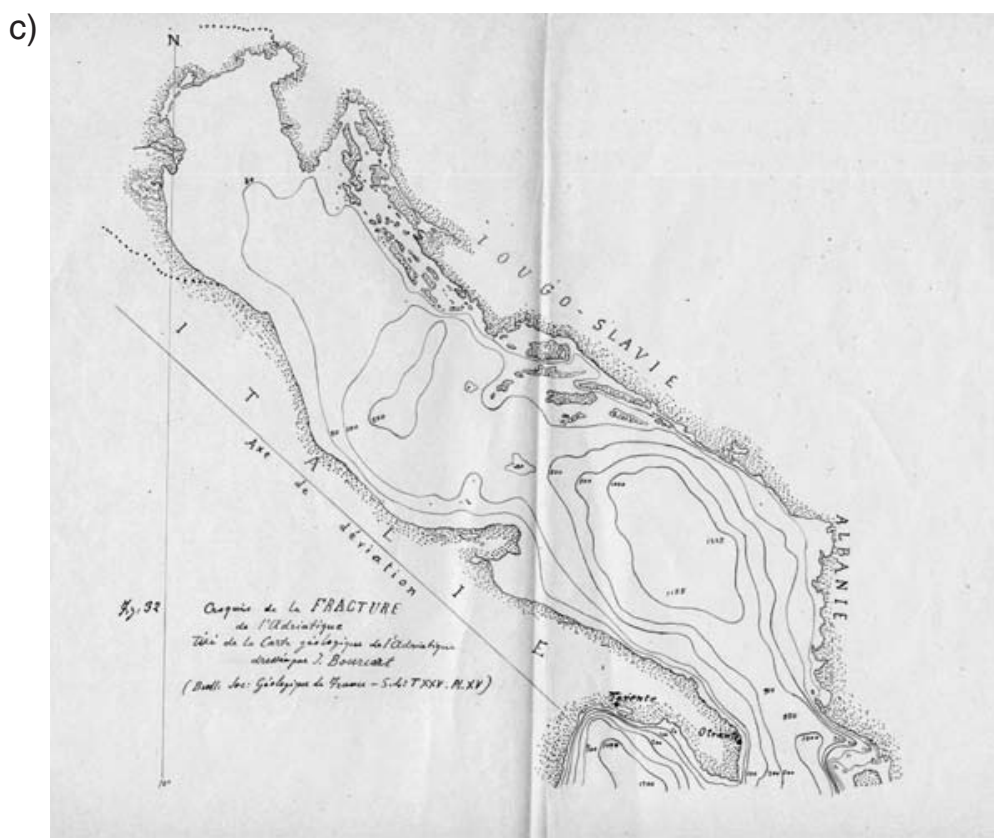

Fig. 8a-c. Some hand-drawn maps from the unpublished manuscript 'dilatation planetaire' of 1932. a) geometrical considerations of Mantovani about the conformity between the coast of Brazil and the Guinea Gulf. The opinion of the Italian was that the non perfect coincidence of the coasts in his fig. 23 shows that the African continent has undergone a deformation, a «deviation towards east of the coast». This problem is know as the Jeffreys objection against the continental drift, and was resolved by Samuel Warren Carey using shiftable transparent spherical caps on a wooden globe to displace the continents on the sphere avoiding the cartographical distortions (Scalera, 2003). b) Outline of the evolution of the Indian Ocean. The arrows indicate the «general deviation and translation toward East of the three peninsulas: Arabia, India and Indochina». c) The Adriatic sea basin was judged by Mantovani as an incipient fracture of the Earth crust. The map was drawn on the base of the Geologic Map of the Adriatic by Jacques Bourcart, the scientist that in 1924 pointed out the work of the Italian to Alfred Wegener.

their originality lies in the fact that, even today, they go well beyond the present theories of mathematicians and physicists.

We ought to have kept to a simple scholarly or academic style, as one always does, for our various demonstrations, but in the present case, it was necessary to set the usual theories side by side with the new conceptions in order to bring out more effectively the difference between the former and the correctness of the latter.

Under these conditions, we were induced to quote many phrases written by the most authoritative scientists, while refraining from giving their names, when that might have given a polemic tone to the demonstrations.

When, however, the words of certain scientists were in agreement with our new conceptions, it was highly fitting to recognize that fact. For example, Prof. Einstein renounced his theory in February 1932 at the Carnegie Institute, saying, «The general principle of relativity is not satisfactorily founded and it needs to be further developed.»

We are pleased to admire his frankness, although we had gone further, before Prof. Einstein had done, in establishing our formula A:EI which goes beyond any possible calculation of space, time and movement.

We ask that you immediately seek fully to grasp the value of that formula since it is at the heart of any demonstration of what Universe and universal radiation are.

R. Mantovani 
Although some of these final statements of Mantovani can be considered the fruit of strong and passionate personal ideas, his attitude towards the investigation of reality and his conviction - shared by Einstein - that our mathematical models of the world are always temporary and can be improved should be judged positively.

However, his reflections on Universal Radiation could not be aired in the normal circuit of scientific publications - and undergo the usual peer review - and this was probably the case, given that, by the author's own admission, they belonged to metaphysics rather than to physics.

\section{Conclusions}

Seeking the merits of the Italian in non-essential ideas such as a configuration of Pangaea similar to that of Wegener, cannot help but conceal his true merit - as the Wegener's quotation does - which he himself strenuously claimed up to his old age: the idea, based on geographical evidence, that the Earth expands as a consequence of general laws of the universe. His awareness that he, like it or not, was the guardian of a highly important truth for all sciences, that it belonged to geography, and that he was defending this discovery in face of the indifference of the academic world, was extremely important.

Could Mantovani have done more? Could he have carried more weight in the scientific debate? Or was the French academic world so aware of the value of his reasoning that they took him into the Geological Society and obliged Wegener to quote him?

One thing is certain: Mantovani could not have produced more than he did because of his activity as a professional musician. Indeed, it is amazing that he managed to keep up to date despite that, and incorporate more and more into his world system (Mantovani, 1930, 1932a, 1932b). Nor could he have made himself more visible with publications in prestigious journals which, then as now, are rather reluctant to accept work from those not considered professionals.

Despite that fact, the academic world - with its characteristic detached at times cold and secret foresightedness - became aware of his presence, and had to interact with him, as a person who surely ought to be listened to. We do not know the details, but a person is presented to the Geological Society only when he has become known and mutual trust has been established.

The same applies to Bourcart (1924) who brought him to Wegener's attention. It should be considered, furthermore, that scientific information circulates more easily among academics and that the works of Yarkovsky (1888, published in French) and Lindemann (1927, published in German) on Earth's expansion as well as all those who preceded Wegener on continental shifts could not have gone unobserved.

Moreover, these were times of tumultuous evolution in the physical sciences, with Einstein's relativity and quantum mechanics that were revolutionizing scientific and philosophical thinking - a fact not to be forgotten.

Hence, it was a period in which every idea had to be taken into account, no matter how far from common sense it may seem to have strayed.

It could be also possible - but not demonstrable - an indirect influence of Mantovani (trough the quotation on the Wegener's book) on later European researchers involved in Earth's expansion like the Berliner Ott Christoph Hilgenberg (1933; 1974; see biographical notes in Hilgenberg, 2003, and Scalera and Braun, 2003).

In a mysterious way known only to the academic world, new ideas that are difficult to associate can be casually kept in the drawer; in this case, academics realized that l'aimable conférencier (the amiable lecturer) Roberto Mantovani (Historical Archives of the Italian Geographic Society) $\left({ }^{18}\right)$ : «[He] is not merely the delicate and conscientious artist so highly esteemed by all those who know him, he is also a scientist and indefatigable researcher» (Anonymous $1^{\text {st }}, 1909$ ) and it took measures to see to it that a trace of his thought remained in the oral communications at the Geological Society.

I like to imagine Mantovani at work at Saint Servan convincing the audience at his lectures, 


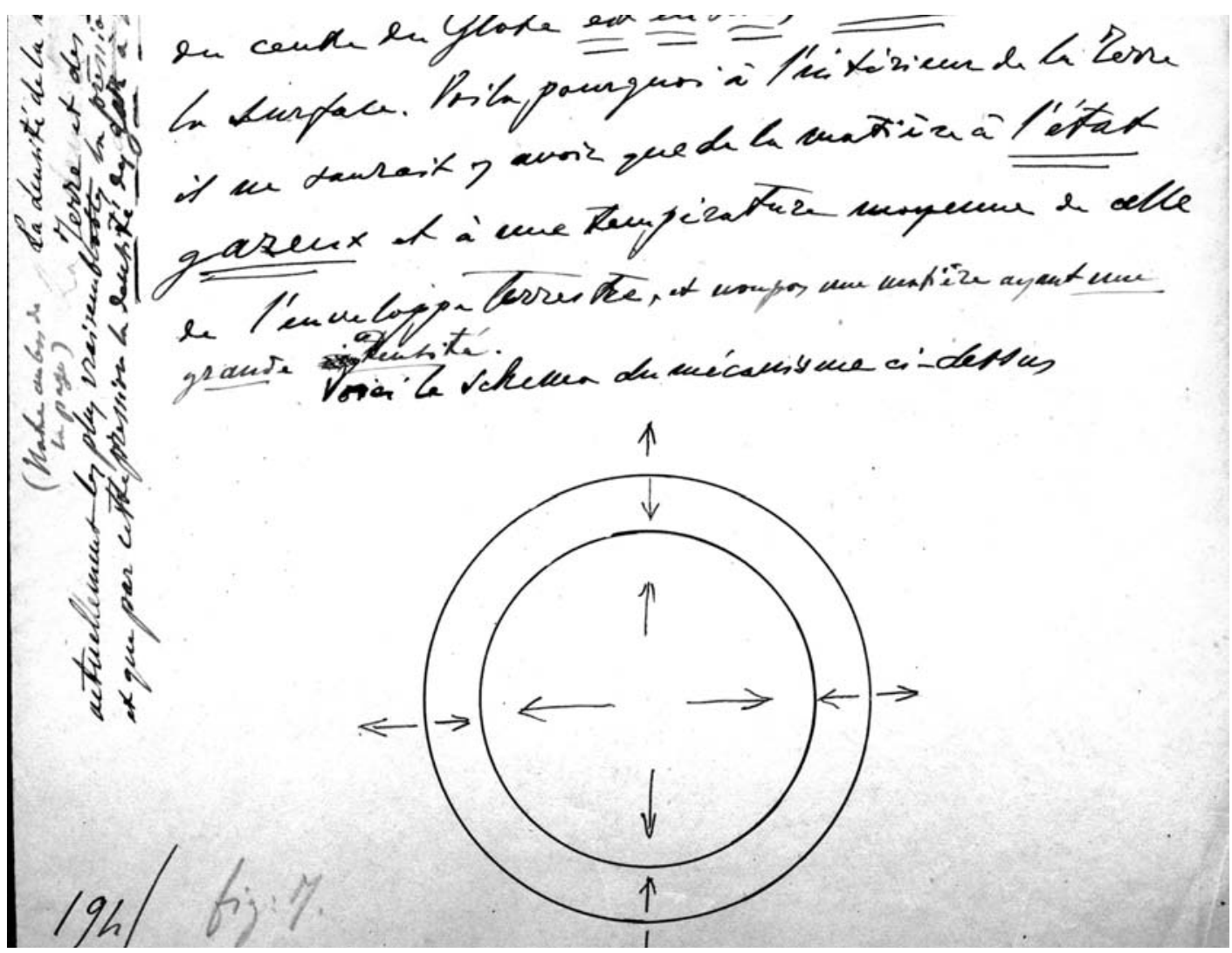

Fig. 9. The sketch of the mechanism of the planetary expansion by the pressure of the inner Earth's material in a high temperature gasiform-state (manuscript Dilatation planétaire of 1932).

as described (Archives of the Italian Geographic Society) by one of the people present (Anonymous $1^{\text {st }}, 1909$, a short news item from the Gazette L'Ouest-Éclair) $\left({ }^{19}\right)$ :

We don't dare assert this, but his well documented and witty lecture, delivered with charming bonhomie and humour was very well received.

Or in a conference held around 1924, which was described by an anonymous journalist (Anonymous $2^{\text {nd }}, 1924$, a short news item from the Gazette Le Matin) $\left({ }^{20}\right)$ :

All the developments of the theory of M. Mantovani are logic in their inventiveness. He has illustrat- ed them by a practical experience, using an inflatable sphere coated by a plastic layer.

Imagine him, then, uttering these words which showed us - besides the world of Christopher Columbus, and thanks to that, as well as to the geographic and cartographic sciences that came thereafter - a new world in its most extreme form of evolution (Mantovani, 1930, pp. 17-18) $\left.{ }^{(21}\right)$ :

If we want to make a projection of the surface of our globe on a flat surface, such that the north pole is at the centre, we discover that the three great continental masses on the terrestrial sphere have separated in some way, due to the expansion of Earth's en- 


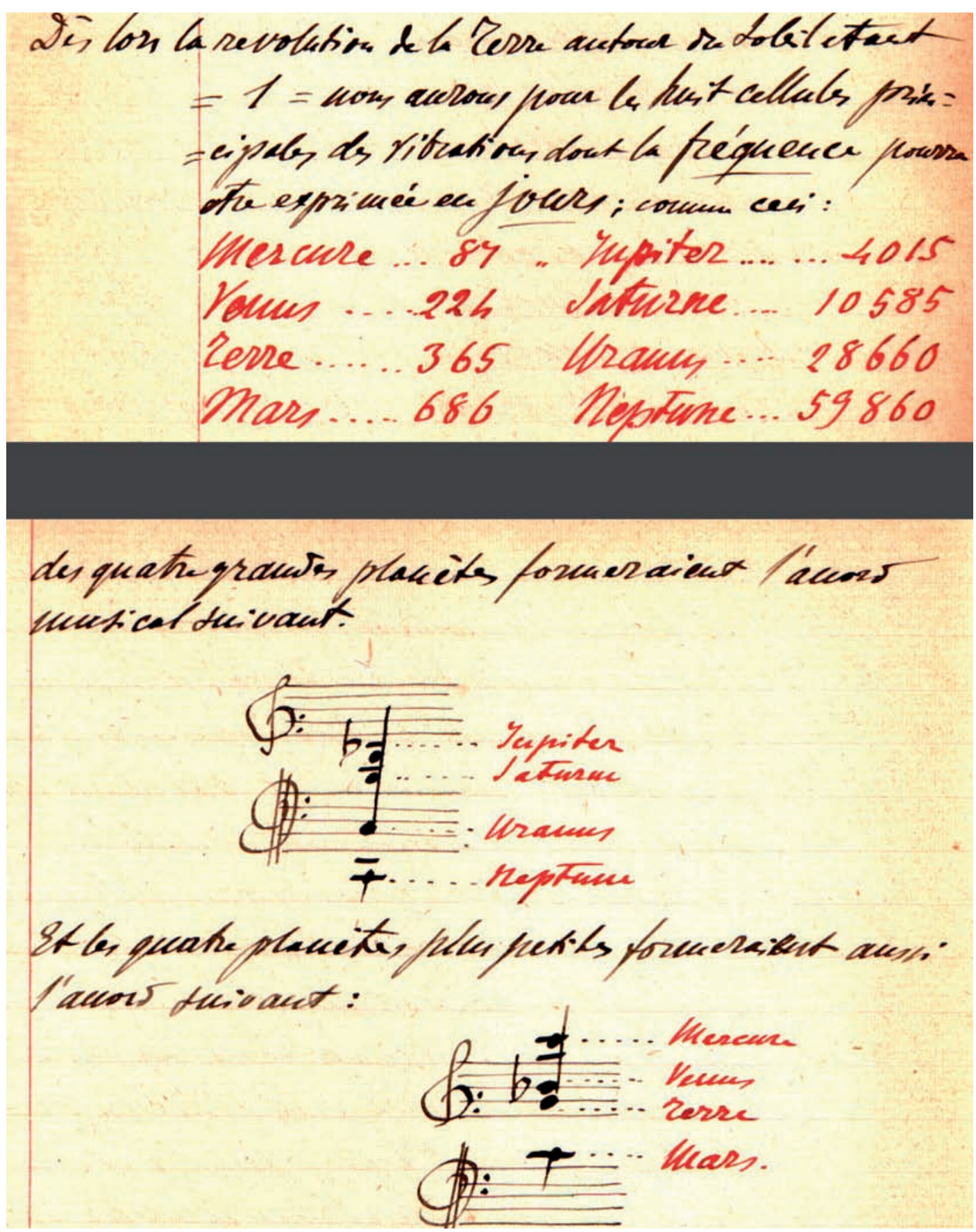

Fig. 10. Two pages of the manuscript Radiation Universelle from 1912, in which Mantovani lists the periods of revolution of the planets considering them as periods of vibration. Then he scales the periods to the musical pentagram, writing two distinct accords, the first for the external planets and the second for the internal ones. 
velope, like three sepals of a flower whose north pole is the peduncle.

Albeit in November 2003 new material has been recovered (figs. 8a-c, 9 and 10) thanks to the descendants, further work remains to be done to reveal other aspects of the life of this artist and scientist, and perhaps other correspondences, musical compositions and manuscripts of his as well.

In the meantime the accords of his music of the planets (fig. 10) will continue to sweetly resound, encouraging all who valiantly defend their creative ideas against a mostly deaf environment.

\section{Acknowledgements}

Thanks for the assistance provided for this research go first of all to the Ministry of Foreign Affairs for having granted access to its historical archives at the Farnesina headquarters, which were essential to the preparation of this text.

For their assistance in this research, we thank Prof. Claudio Cerreti of the Italian Geographic Society, Dr Ezio Vaccari an historian of geoscience at Genoa, Dr Lucia Fornari-Schianchi, Head of the Superintendence of Fine Arts of Parma, Dr Leonardo Farinelli, Head of the Bibliote- ca Palatina, and Dr Marzio Dall'Acqua, Director of the Parma State Archives, Dr Philippe Petout, Director of the Museum of St Malo, Mme Michèle Sacquin Curator of the French National Library. Dr Jean Gaudant and Dr Gabriel Gohau, the President of COFRHIGEO provided invaluable information. Professor Marie-Claire Moussat provided information on the former musical activities of Saint-Servan. Mrs Federica Dondi and Valeria Pezzani of the City of Parma and Sorbolo Registry Office kindly supplied date on the geneology. Professor Claudio Cerreti made it possible to discover some letters from Mantovani to the IGS. Professor Gaspare Nello Vetro kindly allowed us to consult the files of his Dictionary of Musicians of Parma. Thanks are owed to the librarians and archivists of the University of the Isle of La Réunion.

Particular thanks go to Professor Renata Mantovani Pulvirenti for having supplied the first photograph portrait of Roberto Mantovani several years ago, and to Mantovani's French descendants Yvane Mantovani and her husband Alain Poirier as well as their daughter, Catherine-Marie, for having recently contacted me, providing me, with great enthusiasm, the manuscripts, photographs and material cited in these pages and which will be material for future studies. Yvane wrote the letter containing her recollections which is reproduced here as an Appendix 1.

\section{Appendix 1}

My Grandfather, Roberto Mantovani

by one of his granddaughters, Yvane Mantovani Poirier

I take great pleasure in recalling my Italian grandfather. I did not know him very well since he died when I was seven years old. That was on January 10, 1933. Furthermore, my father's colonial career kept us away from France for periods of three years in a row, so we only met our grandparents during leaves of absence, that lasted around six months.

To his grandchildren Babbo (Papà) (Babbo in Italian, especially in the northern regions, is the equivalent of dad, daddy, pa in English. N.o.e.) was the name his parents used, so they also used this name [...].

My first recollection of him goes back to when I was three years old, and this was probably aided by the photos from the family album that had been taken in his apartment in Rue Marcadet in Paris.

This was where the family got together for special occasions such as Christmas. I can still see myself sitting on my grandmother's lap. She showed me postcards from Italy. Her beloved husband was by her side, silent and affectionate. They were seventy and sixty eight years old respectively, and were deeply in love with one another. My grandparents must, however, have moved at the beginning of the nineteen thirties because my recollections go back to an apartment building in the Avenue de Ségur: they had an apartment there, as did their two daughters, unmarried. Both of them worked as secretaries in a Ministry not far from there. 
My grandfather passed away there, and his wife shortly thereafter. They were buried in Samois, near Fontainebleau, in the ground. Their grave is quite simple and near that of their son Italo, whose brilliant career as a judge was cut short by a bad cholera vaccine at the age of thirty four. Italo's wife came from Fontainebleau and had good friends in Samois, so that is why her husband is buried there. My grandparents had been affected by the death of their youngest child and this is why they chose to be buried in that location. We went to dwell on that grave in 1995, and there we had the idea that we could have a plaque placed there that recalled the life and work of Roberto Mantovani.

We have never had much information about his stay in La Réunion; it is said, for example, that he had reached the island with an Italian scientific expedition, that a girl from the high society of the island had caught his fantasy, that she was a good pianist, that he had let his companions go on with their voyage, but that they and their possessions had succumbed in a shipwreck [...].

Roberto married Marie-Anna Piet on 31 August 1880 in the church of St Paul de La Réunion. My grandmother's family was an old Creole family, which had been on the island for centuries: several of my ancestors belonged to a small contingent of young artisans who had responded to a recruitment campaign publicised in posters all over France. They made their trip on a boat called Le Taureau (The Bull), which arrived on July 9, 1665 in the Bay of St Paul.

My grandparents had seven children: Itala, Margherita, Luigia, Roberto, Carlo, Renato (my father) and Italo. Itala died of typhoid fever at the age of approximately sixteen. My father always told me that the family had left La Réunion at the age of four and they lived in England until he was seven. He was born on December 28, 1891 (but his birth was not declared until January 4, 1892). Thus, we know that they must have left La Réunion around 1896 and England, towards 1899. They then settled in Saint Servan, near Saint Malo (now the two towns have merged), in Bd Surcouf which subsequently became Bd Henri Dunant.

We do not know why they chose St Servan. All I do know is that some friend of my grandmother from La Réunion lived there.

The family undoubtedly lived on what was earned from singing and string-instrument lessons that he and his wife gave, but each of the children played an instrument. The small family orchestra gave concerts at home and in the little chapel of St Louis de St Servan. There are still traces of the cello key on the floor, as my husband and I were able to observe.

One of Roberto's goddaughters was a niece, Armande Piet, who had great affection for him. He gave her his grand piano in his will, but we do not know what happened to his violin. We only know that he decided to give it away when he knew that he could no longer play it [...].

My father, Renato (René) inherited his precious manuscripts. Due to the dramatic events of the war and a precarious family situation, he only devote a little time to them. On 7 January 1958, however, after reading an article on Antarctica, in the Figaro of 2 December 1957, he wrote to that newspaper to remind them that, as early as 1889 , his father had formulated a theory on planetary expansion and that, in 1909, had confirmed the existence of an Antarctic archipelago.

In this letter, he wrote: «I have the manuscript concerning this theory. I reread it a short time ago and was struck to see that the phenomena, recently confirmed, such as the existence of gigantic faults and fractures, of enormous canyons slashing deep continental grooves, can be logically explained in theory by planetary expansion, while present-day science is unable to indicate their origin. My father passed away in 1933 and, if the existence of an Antarctic archipelago is formally recognised, you can understand my wish to see that to him should be given the merit of having foreseen it almost fifty years earlier». He enclosed in his letter a copy of an article by Prof. Bourcart that had appeared in La Revue Scientifique on 27 September 1924.

After receiving this letter Le Figaro published an article in which the works of Prof. Roberto Mantovani were mentioned. It was in the 1958, March 23, issue. To the best of our knowledge, nothing came about as a result of this article.

Shortly before his death, my father asked my husband, with whom he had often conversed at length on scientific subjects if, when he had gone to the other world, he could make every effort to make Babbo's work known. Unfortunately, he did not have the time to hand over all the documents in his possession and his wife (my father had remarried after my mother had died) was not willing to give up the rest. She died in the eighties without any known heirs, and we are still looking for these precious documents.

My husband [Alain Poirier; N.o.e.] was not sufficiently versed in the sciences, unfortunately, and he was not convinced by the theory of planetary expansion. It is true that the cause of this expansion (the pressure of gasses in an empty sphere) did not seem to him a theory that could be seriously supported. Every time he spoke of it with some colleagues from the French Astronomical Society (Société Astronomique de France), of which he was a member, (and, at a certain point, a member of the Board of Directors) he only encountered scepticism. 
Once he wrote to Haroun Tazieff, after seeing a television programme, to ask his opinion about this theory. The letter replied on July 22, 1974:

[...] The most current opinion is that the Earth is not expanding. Calculations show that the effect of the distribution of masses that emerged on the rotation of the globe (sic) is insignificant. In fact, you can imagine this, the average of emersion is less than a $1 \mathrm{Km}$, for an Earth's radius that is more than 6300 times greater. Particularly as the average density of this part that has emerged (2.7) is far less than that of the globe (5.5).

There are, however, those who believe in the theory of the expansion of the globe. Among them is Monsieur André Baronnet - Résidence de l'Observatoire, 92190 Meudon - who published two articles on the subject.

Thank you for offering us the opportunity to have a look at the manuscripts of your ancestor, Prof. R. Mantovani. I myself have very little time. [...]

My husband, however, himself very busy providing a living for our family, could not follow up on this invitation to meet M. Baronnet [...].

That last letter my father received from Babbo is one written in French on 24 December 1932 in which he told him:

My dear child, indeed I received your letter concerning the new year and we thank you ever so much and ever so warmly. What you have told me about the newspaper l'Ouest-Eclair that is indeed the case, and, above all, at the end of the year when all the newspaper have so much to say; and, therefore, the science column is always behind the times, even when it is prepared weeks in advance. Here, too, the weather has been wonderful but, in spite of that, our little miseries are always waiting for something better to happen and neither I nor your mother can enjoy the good weather. We continue to hope that - as springtime approaches - we can once again go where the orange trees blossom. The Universal Radiation text is finished. It is about 140 pages and I think my revisions are good enough.

All of our affection to all of you, with best wishes for good fortune next year and for many more, including a good promotion for you in your career. Babbo.

But the «minor disturbances» became more serious; three weeks later, Babbo left this Earth to «embark upon life» (St Thérèse de Lisieux), finally to find out the truth about all that had interested him and aroused his enthusiasm during his fruitful existence.

\section{Notes}

$\left.{ }^{1}\right)$ A parte qualche contrada ancora poco conosciuta e le due regioni strettamente polari, la superficie terrestre è ora perfettamente conosciuta, ed allora ci sembra che nessuna scoperta importante d'origine geografica sia ancora possibile. Eppure si è appunto la perfetta conoscenza sulla forma di tutti i mari, di tutti $i$ continenti e di tutte le isole che ci ha condotti oggidi ad una scoperta importantissima.

[...] la detta scoperta è il complemento naturale delle teorie che due illustri italiani sostennero per primi. Infatti ognuno sa che Colombo colla scoperta d'un nuovo mondo dimostrò che la Terra è rotonda. Venne poi Galileo per sostenere che la Terra pur si muove; ed il caso vuole che un altro italiano venisse terzo in così eletta compagnia per provare che la Terra si dilata!

E ciò che io trovo più curioso in tutto questo si è che quel terzo sono appunto io. Ma poco importa che sia io o un altro se il trio è perfettamente italiano e se la scoperta ha il più grande interesse. Non v'ha dubbio alcuno: l'aver trovato che la Terra si dilata, molto lentamente è vero ma in modo continuo, ha una iportanza grandissima non solamente per la geografia, l'astronomia, la paleontologia [...].

[...]. Ed allora le prove certe e ben visibili della dilatazione che ha subito e che subisce ancora la pellicola che forma tutta la superficie terrestre, appartengono strettamente alla geografia.

( $)$ Only weak or null influence could has had on western culture the tales about the origins contained in the Zoroastian texts, the Avesta-Vendidad [Fargard 2. Yima (Jamshed)]. The deity Yima grants for three time to made the Earth larger, because the space for herds and people became too meagre and insufficient to live with prosperity. But the expansion of the Earth could be interpreted also in a territorial sense. Nicola Oresme (13231382) in his Livre du ciel et du monde (1377) proposed a pure intellectual exercise about a possible increase of the Earth size, with the planet swollen by a growing inner cavity (Parodi, 1981, p. 256; Scalera 1999, p. 163). The passage was contained in a reasoning of Oresme about relativity of space and on our unawareness of a hypothetical process of expansion of all the parts of all the things. Variation of the Earth's globe size - a decreasing size - is quoted in a 1562 book (pp. 5-7) of the Dalmatian Francesco Patrizio da Cherso (1529-1597; Renaissance man of letters and philosopher), in which he reports the tales of Ethiopian sages about the rage of 
Uranus against the haughtiness of the Humankind. Jupiter and Neptune, his sons, were charged to punish the men by shooting lightnings from the sky and trident strokes from the depths. The Earth, constituted by inhabited large and interconnected caves, collapsed from a size comparable to the sphere of the sky to the modest actual size. This tale was probably inherited by the Christian tradition that transformed it in the tale of the fall of the haughty angels. In this Ethiopian case it is more probable that the tale was truly referred to a spherical Earth, because the peoples of the north and south equatorial Africa were aware of the sphericity of our planet as indicated mostly by the inversion of the seasons crossing the equator, and from the observation of a second celestial pole in the southern emisphere.

$\left(^{3}\right)$ Monsieur le Professeur, J'ai lu avec beaucoup d'intérêt votre théorie sur les translations continentales d'après la traduction de M. M. Reichet éditée par A. Blanchard-Paris. 1924.

[...] Permettez moi de porter à votre connaissance que des remarques sur la concordance des côtes du Brésil et de la Guinée avaient été faites par de Saint-Beuve, critique français vers 1860. Une autre remarque semblable, mais plus étendue, avait été faite par Edward Forbes cité par Darwin dans son ouvrage L'Origine des espèces publiée en 1859. Ce Forbes prétendait, nous dit Darwin, que tous les continents et toutes les îles devaient avoir été réunis les uns aux autres à une époque relativement récente; ce que Darwin n'admettait pas, et pour cette raison il ne s'est pas étendu sur ce sujet.

De mon côté en 1878 j'ai visité différents points de l'océan indien, et en septembre de la dite année j'arrivai à l'île de La Réunion (Bourbon). En visitant la rivière de Saint-Denis, près de la ville de même nom et capitale de l'île, je remarquais que le remparts au fond des quels coulait la rivière présentaient une parfaite co(n)cordance dans leur courbes et j'en avais conclu que cette rivière devait être une fracture occasionnée par l'ancienne activité volcanique de l'île.

Des lors, par ma tendance à généraliser les faits, je me suis demandé si une mer ne serait pas aussi une grande fracture de l'écorce terrestre. Ayant consultez. mon Atlas je trouvais de suite en effet que toutes le mers présentaient une analogie complète entre leur côtes malgré la grande distance qui parfois les sépare.

En 1884 j'exposais mes observations au célèbre astronome C. Flammarion qui les trouva fort curieuses et intéressantes. En décembre 1889 je présentais une note sur «Les fractures de l'écorce terrestre» à la Société des Sciences et Arts de l'île de La Réunion et insérée dans le Bulletin de la dite Société année 1889.

Des mes observations j'avais constaté que tous les continents et toutes les îles devaient former un seul bloc à une époque fort reculée. De ceci il en résultait la conséquence bien naturelle et incontestable que la Terre devait être, au temps de la première période de son évolution beaucoup plus petite qu'au jour d'huis; c'est-à-dire, qu'elle devait avoir à peine le tiers de son diamètre actuel. La pellicule superficielle de la membrane terrestre s'étant fendue par la force expansive du gaz nucléaire intérieur qui distendait graduellement et d'une manière excessivement lente la susdite membrane il en est résulté de toute nécessité la translation des continents et des îles. [...].

$\left({ }^{4}\right)$ Albeit also the figure of William Lowthian Green (1819-1890; merchant and several times minister of Hawaiian Governments) is associated to the group of predecessors of the expansion idea (Carey, 1976), in his book of 1875 Vestiges of the molten globe only in a foot-page note, on p. 55, Green quotes a Clarence Dutton (18411912) paper (1874) as a mere confutation of the shrinking of the Earth. Green and Dutton were nor expansionists but only verticalists. Probably it is the case of an historical misunderstanding that has been good faith propagated from person to person.

$\left(^{5}\right)$ Parma, 20 sett. 1930 - VIII, Illustrissimo Signore, Da parecchi anni sono stabilito a Parigi e sono venuto a Parma in luglio scorso per rivedere molti dei miei parenti. Prima di far ritorno in Francia desidererei grandemente di fare una comunicazione o meglio una conferenza a codesta onorevolissima Società Geografica, sulla morfologia continentale in presenza di S.E. il Capo dello Stato l'on. Mussolini. Mi permetto di indirizzarmi alla S.V. Illustrissima per sapere se e quando tale cosa sarebbe possibile. Fiducioso nella bontà di Vostra Signoria, La prego di volermi tenere per scusato e di aggradire i sensi del mio più profondo ossequio. Prof. R. Mantovani, Strada Cairoli 10 - Parma / Parigi - Rue Marcadet 151 bis.

$\left(^{6}\right)$ Roma, 22 Settembre 1930 - VIII. Egregio Professore, In risposta alla sua lettera del 20 Settembre u.s. pregiomi informarla che l'ottenere ad una conferenza l'ambita presenza del Capo del Governo è cosa insperabile. In quanto a tenere una conferenza ai Soci della R. Società Geografica Italiana sul tema che Ella propone sarebbe certo cosa gradita. Ma poiché esiste una Commissione per le Conferenze sarebbe doveroso sottoporre al suo giudizio l'opportunità di tenerla o no, qui o altrove. Se Ella pertanto ritiene di inviare in comunicazione o una copia o un largo riassunto, mi farò dovere di farle poi conoscere qualcosa al riguardo. Per intanto, se Ella crede, di farsi Socio, Le unisco una scheda. Ossequi, Il Segretario.

(7) Parigi, 8 novembre 1930. Illustrissimo Signore, Quando ebbi l'onore di presentarLe una copia del mio opuscolo «La Terre grandit» ho dimenticato di dirLe che tale lavoro era pieno di errori di stampa. Ne sono dispiaciutissimo e Le domando profondamente scusa. 
L'opuscolo non è corretto perché il direttore della tipografia è stato ammalato per alcune settimane e gli operai non erano atti a comprendere il testo in lingua francese malgrado le mie molteplici correzioni, finché alla fine sono stato obbligato di ritirare il lavoro incompleto.

Avevo poi desiderato di fare una conferenza in codesta Reale Società Geografica sulle «forme continentali» perché queste sono interamente del dominio della Geografia epperciò avrei trovato costé le carte e la sfera terrestre necessaria alle mie dimostrazioni ed evitare così l'obbiezione possibile che le carte fossero per parte mia adattate allo scopo.

Trattandosi poi non di una mera ipotesi ma di una vera ed importantissima scoperta atta a sconvolgere interamente le leggi fisiche e tutte le concezioni astronomiche attuali, credevo, non per me personalmente che valgo ben poco, ma per la gloria della scienza italiana, che la presenza di S.E. il Capo del Governo alla conferenza sarebbe stata convenevolissima per dare alla rivelazione d'una scoperta importantissima italiana tutta l'importanza voluta. Infatti se Cristoforo Colombo scoperse un nuovo mondo, la dilatazione planetaria ci mena direttamente alla scoperta di un nuovo Universo.

Mi permetto intanto di spedirle con lo stesso corriere un altro esemplare del mio opuscolo nel quale ho contrassegnato in rosso gli errori di stampa e tutte le frasi importanti.

Prego di nuovo V.S. Illustrissima di volermi tenere per iscusato ed aggradire i sensi del mio profondo ossequio. Prof. R. Mantovani - Parigi 151bis rue Marcadet, $18 m o$.

$\left({ }^{8}\right)$ Recognition and license to perform the duties of consul and arbiter between two different legislations granted from a foreign state to a new consul.

(') C'était vers le commencement de l'année 1879, je venais d'arriver à La Réunion, lorsqu'un jour en me promenant sur un des bords de la rivière de Saint-Denis, je remarquai la parfaite ressemblance de forme qui existe entre les deux remparts de cette rivière; non seulement les proéminences de l'un des bords correspondaient au creux de l'autre bord, mais aussi les différentes couches de lave étaient superposées dans le même ordre des deux côtés. Je pensai donc que la rivière de Saint-Denis ne pouvait être qu'une fracture du sol due à l'activité volcanique de l'île. Par une tendance à généraliser les idées, je me posai aussi cette question: Si une rivière est une petite fracture du sol, pourquoi une mer ne serait-elle pas une grande fracture de l'écorce terrestre?

Rentré chez moi et jetant un regard sur un planisphère, je fus très étonné de constater que le côtes opposées des mers offraient, en général, la même ressemblance de forme que j'avais remarquée entre les deux bords opposés de la rivière de Saint-Denis. Cela m'encouragea vivement à étudier cette nouvelle manière d'envisager les plis, les bosses, et les creux de la surface terrestre. [...]

Si nous rapprochons dans notre imagination, ou sur une sphère, tous les bords des mers nous réduisons au quart environ la superficie de notre globe; et si nous ajoutons à notre calcul les rapprochements des bords, des fractures qui ont produit des fleuves, des lacs, des vallons, des plaines, etc., nous arrivons facilement à un globe nous rappelant de beaucoup, par ses dimensions, la petit planète Mercure. Nous sommes donc obligé de reconnaître que l'écorce terrestre a augmenté considérablement en superficie aux dépens de ses enveloppes liquide et atmosphérique.

$\left.{ }^{(10}\right)$ Nous verrons à son retour s'il y aura lieu d'y apporter de grandes corrections pour les détails, car pour l'ensemble, l'origine, la forme et l'étendue de l'Antarctide resteront telles que nous venons de le déterminer.

${ }^{(1)}$ [...] les géologues ont trouvé de grandes analogies entre les terrains qui forment actuellement l'Amérique du Sud, l'Afrique australe, Madagascar et l'Australie et cela se conçoit sans peine puisque, comme nous venons de le voir, toutes ces contrées aujourd'hui si éloignées l'une de l'autre étaient primitivement réunies.

${ }^{(2)}$ Dès lors, il est évident que l'Antarctide, ayant été formée par les fragments restés en arrière de ces continents pendant l'écartement qu'ils ont subi, elle doit de toute nécessité former un grand Archipel présentant de grandes affinités géologiques avec l'Amérique du Sud, l'Afrique et l'Australie.

${ }^{\left({ }^{13}\right)}$ Chacun sait qu'à la surface de notre soleil il se produit à certaines époques surtout de jets de matière d'une telle puissance qui peuvent atteindre en hauteur plus du quart du diamètre du soleil. Qu'est-ce que la Terre avec ses 12.000 kilomètres de diamètre comparée à telles éruptions? Or le sommet de certains jets de cette matière vont atteindre la région 800.000 kilomètres où l'action directe de l'attraction du soleil est moindre dès lors cette partie de la matière solaire projetée, en raison du mouvement tourbillonnant reçu, suit en partie la rotation du soleil sur lui même, et en tournant aussi sur elle-même, arrive à former au cours des temps une minuscule cellule planétaire constituée à l'instar de la cellule mère, le soleil; nous avons alors tous les éléments qui constituent la famille solaire et dont les différents membres nous représentent la série complète des phases de l'évolution de chacun d'eux. Toute évolution d'une planète se résume ainsi en trois périodes bien caractérisées: 1) Période tourbillonnaire. 2) Période planétaire. 3) Période cométaire. La Terre se trouve actuellement en pleine période planétaire ou autrement dit en voie de développement.

$\left.{ }^{14}\right)$ L'âge d'une fracture doit être en proportion directe de son maximum d'écartement, car la supposition la plus logique est d'admettre qu'une cause unique agissant d'une manière uniforme doit avoir produit toutes les fractures de l'écorce terrestre. La première fracture est donc celle qui a formé l'Océan Pacifique. 
$\left({ }^{15}\right)$ En admettant provisoirement un écart d'un millimètre par siècle entre le côtes du Pérou et la côte du Mozambique (Océan Indo-Pacifique), nous arrivons à 26 milliards de siècles environ pour l'écart actuel Indo-Pacifique; et à 7 milliards de siècles pour l'Océan Atlantique.

${ }^{\left({ }^{16}\right)}$ Le milieu intersidéral est aussi plein qu'un ouf, si vous voulez bien me permettre cette expression; et il y a là des courants, des tourbillons, et des couches de différente épaisseur exactement comme dans notre propre atmosphère.

$\left({ }^{17}\right)$ Paris 1 Janvier 1933. Préface. Les idées exposées dans ce livre (La Radiation Universelle) remontent à un demi siècle et leur nouveauté réside dans le fait qu'elles vont encore aujourd'hui bien au delà des théories actuelles des physiciens et mathématiciens.

Pour les diverses démonstrations nous aurions dû nous en tenir strictement, comme on le fait toujours, au style simple scolaire ou universitaire, mais dans le cas présent il était nécessaire de mettre en parallèle les théories usuelles avec les conceptions nouvelles à fin de mieux faire ressortir la différence des premières et la justesse des dernières.

Dans ces conditions nous avons été amené à citer bien de phrases écrites par le savants les plus autorisées, en nous abstenons de citer leurs noms, lorsque cela aurait pu donner un caractère polémique aux démonstrations. Cependant lorsque le dire de certaines savants concordait assez avec nos conceptions nouvelles il était de tante justice de le reconnaître. Ainsi par exemple lorsque le profr. Einstein a renié sa théorie en février 1932 à l'Institut Carnegie en disant "La fondation du principe général de la relativité n'est pas satisfaisant et elle a besoin d'être développée plus avant». Nous sommes heureux d'admirer sa franchise malgré que nous soyons alléz plus loin avant le prof Einstein, en établissant notre formule A.E.I qui va au delà de tout calcul possible sur l'espace, le temps et le mouvement.

Nous prions instamment de chercher à bien saisir la valeur de la dite formule car elle constitue la base de toute démonstration de ce qu'est l'Univers et la radiation universelle. $R$. Mantovani.

$\left.{ }^{(18}\right)[\ldots]$ n'est pas seulement l'artiste délicat et consciencieux si estimé de tous ceux qui le connaissent, c'est encore un savant et un infatigable chercheur.

$\left({ }^{19}\right)$ Nous n'osons pas l'affirmer, mais sa conférence fort documentée, spirituelle, faite avec une bonhomie charmante et une pointe d'humour a été fort goûtée.

$\left(^{20}\right)$ Tous les développements de la théorie de M. Mantovani sont logiques dans leur ingéniosité. Il les a illustrés par l'expérience, au moyen d'une sphère dilatable revêtue d'un enduit.

$\left({ }^{21}\right)$ Si nous voulons faire une projection de la surface de notre globe en la posant à plat, de manière à avoir comme centre de la projection le pôle nord, nous trouvons comme sur la sphère terrestre que les trois grandes masses continentales par la dilatation de l'enveloppe terrestre, se sont séparées en quelque sorte, comme trois sépales d'une fleur dont le pôle nord serait le pédoncule.

\section{REFERENCES}

Archives

Archivio Storico del Museo Etnografico Luigi Pigorini (Luigi Pigorini Ethnographic Museum Historical Archives)

Archivio Storico della Società Geografica Italiana (Historical Archives of the Italian Geographic Society).

Archivio Storico Diplomatico della Farnesina, Ministero degli Affari Esteri (Historical and Diplomatic Archives of the Farnesina, Ministry of Foreign Affairs).

Archivi Servizi Demografici di Parma (Parma Demographic Service Archives).

Archivio della Famiglia Poirier-Mantovani (Archives of the Poirier-Mantovani Family)

\section{Bibliography}

Alfano, G.B. (1915): In memory of prof. Giuseppe Mercalli, Atti Accademia Napoletana scientifico-letteraria, anno II, vol. II, fasc. I, n. 7, 3-19.
Anonymous $1^{\text {st }}$ (1909): Saint Servan - La Conférence Mantovani - Une étonnante découverte - La théorie de la dilatation planétaire. A short news item from the Gazette L'Ouest - Éclair de Rennes on March 27, 1909.

ANONYMOUS $2^{\text {nd }}$ (1924?): La Terre grandit-elle? A short news item from the Gazette Le Matin (without date).

ARP, H. (1989): La contesa sulle distanze cosmiche e le quasar (The cosmic distances struggle and the quasars), (Jaca Book, Milano).

BACON, F. (1620): Novum Organum, sive Indicia Vera, de Interpretatione Naturae, (Italian translation and introduction by ENRICo De MAs, 1968, Laterza, Bari).

BOURCART, J. (1924): Les origines de l'hypothèse de la dérive des continents, Revue Scientifique, 563-564.

BRush, S.G. (1980): Discovery of the Earth's core, American Journal of Physics, 48, 705-723.

Bulzoni, G. (1997): Private communications.

CAilleuX, A. (1968): Anatomia della Terra (Anatomy of the Earth), (Il Saggiatore, Milano).

Cailleux, A. (1976): Géologie Générale,Terre-LunePlanètes, (Masson, Paris).

CAREY, S.W. (1976): The Expanding Earth, (Elsevier, Amsterdam). 
CAREY, S.W. (1988): Theories of the Earth and Universe A History of Dogma in the Earth Sciences, (Stanford University Press, Stanford, California).

CiARDI, M. (2002): Atlantide - Una controversia scientifica da Colombo a Darwin (Atlantis -A scientific controversy from Columbus to Darwin) (Carocci, Roma).

DARWIN, C. (1840): On the connexion of certain volcanic phenomena in South America; and on the formation of mountains chains and volcanoes, as the effect of the same power by which continents are elevated, Transaction of the Geological Society of London, 2d ser., pt. 3, 601-631. Reprinted in P.H. BARRETT (ed.) (1977): The collected papers of Charles Darwin (The University of Chicago Press, Chicago).

DARWIN, C. (1897). Geological observations - on the volcanic islands and parts of south America visited during the voyage of H.M.S. 'Beagle', (Third edition, Appleton and Co., New York).

Descartes, R. (1664): Principia Philosophiae, in E. GARIN (ed.) 1967, vol. II, (Laterza, Bari).

Dick, T. (1838): Celestial Scenery: Or, the Wonders of the Planetary System Displayed - Illustrating the Perfections of Deity and a Plurality of Worlds, With an Introductory Essay, By Rev. C. S. Henry. Brookfield: E. and L. Merriam.

Donnelly, I. (1949): Atlantis: The Antediluvian World, A modern revised edition (edited and enlarged by $\mathrm{E}$. Sykes on the 1882 original Donelly's book), (Gramercy Publishing Company, New York).

Drayson, A.W. (1859): The Earth we Inhabit, its Past, Present and Probable Future, (Bennett, London).

Dubard, P. (1958): L'Antartique: Continent ou Archipel?, Le Figaro, 23 March 1958.

DutTon, C.E. (1874): A criticism upon the Contractional Hypothesis, American Journal of Science, 3rd Series, 8, $113-123$.

EgYed, L. (1963): The expanding Earth?, Nature, 197, $1059-1060$

Fossa-MANCINI, E. (1924): La recente teoria della deriva dei continenti in un vecchio manoscritto di Domenico Lovisato (The recent theory of the continental drift in an old manuscript of Domenico Lovisato), Urania, 6, 123-129.

Galizzi, A. and Palmer, R. (1985): La Morte Nera (The Black Death), Kos, 18, 17-48.

GoODACRE, A. (1991): Continental drift, Nature, 354, 261.

GoHAU, G. (1990): Mantovani et sa théorie de la dilatation planétaire, Travaux du Comité Français d'Histoire de la Géologie, (Troisième série, t. IV, séance du 23 mai 1990), 53-58.

GoHAU, G. (1991): Considérations historiques à propos de la théorie de l'expansion terrestre, Sciences, Revue trimestrielle de l'AFAS, 91 (avril), 18-29.

GREEN, W.L. (1875): Vestiges of the molten globe as exhibited in the figure of the Earth, volcanic action and physiography, (Stanford, London).

Hallam, A. (1987): Le grandi dispute della geologia (The great struggles of the geology), (Zanichelli, Bologna).

HANDLIRSCH, A. (1913): Beiträge zur exakten Biologie, Akademie der Wissenschaften in Wien, MathematikNaturwissenschaften Klasse, Bd. CXXII, Abt. I.

HilgENBERG, O.C. (1933): Vom wachsenden Erdball (The Expanding Earth), (Giessmann \& Bartsch, Berlin).
HILGENBERG, O.C. (1974): Geotektonik, neuartig gesehen (Geotectonics, seen in a new way), Geotektonische Forshungen, 45.

HilgenBeRg, H. (2003): The life and work of Ott Christoph Hilgenberg, as seen by his daugther, Helge Hilgenberg, in Why Expanding Earth? A book in Honour of Ott Christoph Hilgenberg, edited by G. SCALERA and K.-H. JACOB, Proceedings of the 3rd Lautenthaler Montanistisches Colloquium, Mining Industry Museum, Lautenthal (Germany) May 26, 2001, INGV, Roma, 43-49.

Houllevigue, L. (1932): Causerie scientifique - La révision des longitudes, Article on the newspaper Temps, 7 June 1932.

IMERONI, A. (1927): Domenico Lovisato: la vita e le opere (Domenico Lovisato: Life and work), Mediterranea, 11-12, 5-42.

LINDEMANN, B. (1927): Kettengebirge kontinentale zerspaltung und erdexpansion, (Fischer, Jena).

MANTOVANI, R. (1888): Réforme du calendrier, Bulletin de la Société des Sciences et Arts de La Réunion, 13, 39.

MANTOVANI, R. (1889): Les fractures de l'écorce terrestre et la théorie de Laplace, Bulletin de la Société des Sciences et Arts de La Réunion, 41-53.

MANTOVANI, R. (1909): L'Antarctide, Je m'instruis. La science pour tous, 38, 19 september, 595-597.

MANTOVANI, R. (1910): Cosmogonie préhistorique et ancienneté de l'Homme civilisé, Je m'instruis. La science pour tous, 21, 22 Mai, 324-326.

MANTOVANI, R. (1910): Cosmogonie préhistorique et ancienneté de l'Homme civilisé (Suite et fin), Je m'instruis. La science pour tous, 22, 29 Mai, 341-344.

MaNTOVANI, R. (1912): La Radiation Universelle, Unpublished manuscript of 192 handwritten pages on a bounded copy-book.

Mantovani, R. (1922): Le secret de Paganini, méthode des méthodes de violon, (Librarie Hachette, Paris).

MANTOVANI, R. (1924): Les points de contact entre la théorie de la dilatation planétaire et la théorie de la dérive des continents de Wegener, Compte-Rendu sommaire de Séance de la Société Géologique de France, 16, 167-168.

Mantovani, R. (1927): L'Atlantide et la découverte de la dilatation planétaire. Compte-Rendu sommaire de Séance de la Société Géologique de France, 4, XXVII, 153-155.

Mantovani, R. (1930): Troublante Découverte: La Terre Grandit. Notice preliminaire sur la découverte de la dilatation planétaire destinée aux mathématiciens, physiciens, astronomes, géologues et à tous ceux qui s'intéressent aux grandes énigmes de l'Univers, (Parma: Printed by the author, Tipografia E. FERRARI).

Mantovani, R. (1932): La Radiation Universelle. Conceptions nouvelles sur les phénomènes de l'Univers, Unpublished manuscript of 69 unbounded double handwritten pages with an introduction and four double pages of conclusions

MANTOVANI, R. (1932): La dilatation planétaire (attributed title), Second part (the first part is missing) of an unpublished manuscript on unbounded handwritten pages (from p. 164 to p. 263).

MoHorovicic, A. (1909): Das Beben vom 8-X-1909, Jahrbuch des Meteorologischen Observatoriums in Zagreb, 9, 1-63.

Morello, N. (1979): La macchina della Terra: Teorie geologiche dal seicento all'ottocento (The Machine of the 
Earth: Geologic Theories from XVII to XIX century) (Loescher, Torino).

MuIR Wood, R. (1985): The Dark Side of the Earth, (Allen \& Unwin, London).

MussaT, M.C. (1996): Private communication about the musical activities of Mantovani deduced from the contemporary press.

NOËL, D. (1989): NUTEERIAT: Nut trees, the expanding Earth, Rottnest Island, and all that, (Cornucopia Press, Perth).

OldHAM, R.D. 1906. The Constitution of the Interior of the Earth as Revealed by Earthquakes. Philosophical Magazine, 12, 165-166.

Olive, P. and A. BARONNET (1964): A propos de l'expansion de la Terre, Science et Nature, 63, Mai-Juin, 29-37.

ORESME, N. (1377): Le livre du ciel et du monde. I, 24, in Tempo e spazio nel Medioevo. Anthology, edited by M. PARODI, (Sez. III, document 14, Loescher, Torino, 1981).

Owen, R. (1857): Key to the geology of the globe - An essay, designed to show that the present geographical, hydrographical, and geological structures, observed on the Earth's crust, were the result of forces acting according to fixed, demonstrable laws, analogous to those governing the development of organic bodies, (Stevenson \& Owen, W.T. Berry \& Co., Nashville, Tennessee).

PAROdI, M. (1981): Tempo e spazio nel Medioevo (Time and space in the Middle Ages). Anthology, Sez. III, document 14, Loescher, Torino.

Patrizio, F. (DA Cherso) (1562): Della Retorica. Dieci Dialoghi. $\left[I^{\circ}\right.$ dialogo] (About the Rhetoric. Ten Dialogues. [ $1^{\text {st }}$ dialogue]), (Francesco Senese, Venezia).

Petout, P. (1995): Private communication from the Director of the Museum of Saint Malo.

Pilla, L. (1847): Trattato di Geologia (Treatise of Geology), (First Part, Tipografia Vannucchi, Pisa).

PlACET, F.F. (1668): La corruption du grand et petit monde. Où il est montré, que toutes les Creatures qui composent l'Univers, sont corrompués par le peché d'Adam [...], (Third edition, Alliot \& Alliot, Paris).

PoIRIER, A. (2005): Private communication and photo of Villa Sivori.

Proviero, A. (1926): Sull'uso dello smorzamento nei sismometri (About the use of the damping in the sismometers), Rendiconti della Reale Accademia Nazionale dei Lincei, classe scienze fisiche matematiche e naturali, vol. III, ser. $6^{\text {a }}, 1^{\circ}$ sem., 321-324.

SCALERA, G. (1995): Terra in espansione (Expanding Earth), Voce per la Enciclopedia delle Scienze Fisiche, vol. VI, (Istituto per la Enciclopedia Italiana Treccani, Roma), pp. 228-231.

SCALERA, G. (1997a): Un musicista scienziato a cavallo tra 800 e 900: Roberto Mantovani e la teoria della dilatazione planetaria, Atti del XVI Congresso Nazionale di Storia della Fisica e dell'Astronomia, Centro Volta, Villa Olmo, Como 24-25 maggio 1996, (Lipomo (Como), Tipografia Nani), 625-642.

SCALERA, G. (1997b): The relation among seismic activity, volcanic rock emplacement and Bouguer anomalies in Italy, Natural Hazards, 15, 165-181.

SCALERA, G. (1999): I moti e la forma della Terra (Motions and shape of the Earth), (Tangram - Istituto Nazionale di Geofisica, Roma).
SCALERA, G. (2001): Nuovi Concetti in Tettonica Globale (con una appendice sulla deriva secolare del polo), in Il ruolo della Matematica nella società contemporanea, edited by A. Laforgia, F.M. Dellisanti, O. FilipPi, M.P. GIOVInE and G. IsERniA, Atti del Congresso della Mathesis (Società italiana di Scienze Matematiche e Fisiche), Barletta 17-19 Ottobre 2000, (Editrice Rotas, Barletta), 343-375.

SCALERA, G. (2003a): Roberto Mantovani an Italian defender of the continental drift and planetary expansion, in Why Expanding Earth? A Book in Honour of Ott Christoph Hilgenberg, edited by G. SCALERA and K.-H. $\mathrm{J}_{\mathrm{ACOB}}$, Proceedings of the 3rd Lautenthaler Montanistisches Colloquium, Mining Industry Museum, Lautenthal (Germany) May 26, 2001, INGV, Roma, 71-74.

SCALERA, G. (2003b): Samuel Warren Carey. Commemorative memoir, in Why Expanding Earth? A book in Honour of Ott Christoph Hilgenberg, edited by G. SCALERA and K.-H. JACOB, Proceedings of the 3rd Lautenthaler Montanistisches Colloquium, Mining Industry Museum, Lautenthal (Germany) May 26, 2001, INGV, Roma, 85-95.

SCALERA, G. (2007): Geodynamics of Wadati-Benioff zone earthquakes: The 2004 Sumatra earthquake and other great earthquakes, Geofísica Internacional, 46, 19-50.

SCALERA, G. (2008): Great and Old Earthquakes against great and old Paradigms - Paradoxes, historical roots, alternative answers, Advances in Geosciences, 14, 41-57.

Scalera, G. and T. Braun (2003): Ott Christoph Hilgenberg in twentieth-century Geophysics, in Why Expanding Earth? A book in Honour of Ott Christoph Hilgenberg, edited by G. SCALERA and K.-H. JACOB, Proceedings of the 3rd Lautenthaler Montanistisches Colloquium, Mining Industry Museum, Lautenthal (Germany) 26 May, 2001, INGV, Roma, 25-41.

SCAlERA, G. and A. Meloni (1991): L'evoluzione della Terra (The Evolution of the Earth), (Casa Editrice Dedalo, Bari).

Scherer, A. (1994): La Réunion, (Presses Universitaries de France, Paris).

Segala, M. (1990): La favola della Terra mobile. La controversia sulla teoria della deriva dei continenti (The tale of the mobile Earth. The dispute about the continental drift theory), (Il Mulino, Bologna).

SNIDER-Pellegrini, A. (1858): La Création et ses mystères dévoilés. Ouvrage ou l'on expose clairement la nature de tous les étres, les éléments dont ils sont composés et leurs rapports avec le globe et les astres, la nature et la situation du feu du soleil, l'origine de l'Amérique et de ses habitants primitifs, la formation forcée de nouvelles planètes, l'origine des langues et les causes de la variété des physionomies, le compte courant de l'Homme avec la Terre, etc., (Avec dix gravures, Frank e Dentu, Paris).

TERMIER, P. (1922): A la gloire de la Terre, (Huitième édition, Desclée De Brouwer et Cie, Paris).

Tuloup, F. (1984): Saint-Malo, histoire générale, (Deuxième édition, Editions Klincksieck, Paris).

VARIOUS AUTHORS (1859): La création et ses mystères dévoilés. Premier recueil des observations critiques concernant cet ouvrage, (Voitelain et C., Paris).

Vening-MeinesZ, F.A. (1926): Gravity survey by submarine via Panama to Java, The Geographic Journal, 71, 144-159. 
Vistoli, F. (2007): Gaetano Manzoni, Voce per il Dizionario Biografico degli Italiani (Article for the Italian's Biographical Dictionary), (Istituto dell'Enciclopedia Italiana Treccani, Roma) (in the press).

VlaAR, N.J. (1989): Vening Meinesz. A student of the Earth, EOS, February 28, 129-140.

Von IHERING, H. (1907): Archhelenis und Archinotis, Gesammelte Beiträge zur Geschichte der Neotropischen Region, (Engelmann, Leipzig).

Wegener, A. (1912a): Die Entstehung der Kontinente, Geologische Rundschau, 3, 276-292.
Wegener, A. (1912b): Die Entstehung der Kontinente, Petermanns Geographische Mitteilungen, 58, 185-195; 253-256; 305-309.

Wegener, A. (1936): Die Entstehung der Kontinente und Ozeane, (Braunschweig, Vieweg \& Sohn, $5^{\text {th }}$ posthumous edition, Italian translation by CLARA GIUA, 1976, Boringhieri, Torino).

YARKOVSKY, J. (1888): Hypotèse cinétique de la gravitation universelle en connexion avec la formation des éléments chimiques, (Chez l'Auteur, Moscow). 